FONDAZIONE ENI

ENRICO MATTEI

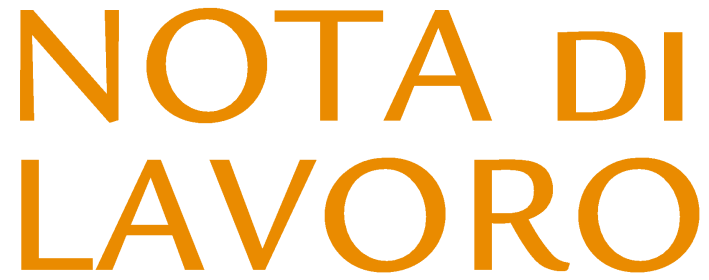

19.2017

Sensitivity of Modeling Results to Technological and Regional Details: The Case of Italy's Carbon Mitigation Policy

Gabriele Standardi, FEEM and CMCC

Yiyong Cai, CSIRO and CAMA, Australian National University

Sonia Yeh, Chalmers University of

Technology 


\section{Climate Change: Economic Impacts and Adaptation Series Editor: Francesco Bosello}

\section{Sensitivity of Modeling Results to Technological and Regional Details: The Case of Italy's Carbon Mitigation Policy}

By Gabriele Standardi, FEEM and CMCC

Yiyong Cai, CSIRO and CAMA, Australian National University

Sonia Yeh, Chalmers University of Technology

\section{Summary}

Model differences in technological and geographical scales are common, but their contributions to uncertainties have not been systematically quantified in the climate policy literature. This paper carries out a systematic assessment on the sensitivity of Computable General Equilibrium models to technological and geographical scales in evaluating the economic impacts of carbon mitigation policies. Taking Italy as an example, we find that the estimation for carbon price and the economic cost of a decarbonization pathway by means of a model with technological and regional details can be lower than a model without such details by up to $40 \%$. Additionally, the effect of representing regional details appears to be far more important than the effect of representing the details of electricity technology in both the estimated carbon prices and the estimated economic impacts. Our results for Italy highlight the importance of modeling uncertainties of these two key assumptions, which should be appropriately acknowledged when applying CGE models for policy impact assessment. Our conclusions can be generalized to different countries and policy scenarios not in terms of absolute numbers but in terms of economic explanations. In particular, intranational trade and the sub-national sectoral/technological specialization are important variables for understanding the economic dynamics behind these outcomes.

Keywords: Computable General Equilibrium, Carbon Mitigation Policy, Sensitivity, Technology, Sub-national regions

JEL Classification: C68, Q5, Q55

This is a pre-print version of Gabriele Standardi, Yiyong Cai and Sonia Yeh, Sensitivity of Modeling Results to Technological and Regional Details: The Case of Italy's Carbon Mitigation Policy, Energy Economics, ISSN 0140-9883, http://dx.doi.org/10.1016/j.eneco.2017.01.021

Address for correspondence:

Gabriele Standardi

Fondazione Eni Enrico Mattei

Isola San Giorgio Maggiore 8

30124 Venice

Italy

E-mail: gabriele.standardi@feem.it 


\title{
Sensitivity of Modeling Results to Technological and Regional Details: The Case of Italy's Carbon Mitigation Policy
}

\author{
Gabriele Standardi ${ }^{\mathrm{a}, \mathrm{b}, *}$, Yiyong Cai ${ }^{\mathrm{c}, \mathrm{d}}$ and Sonia $\mathrm{Yeh}^{\mathrm{e}}$
}

\begin{abstract}
Model differences in technological and geographical scales are common, but their contributions to uncertainties have not been systematically quantified in the climate policy literature. This paper carries out a systematic assessment on the sensitivity of Computable General Equilibrium models to technological and geographical scales in evaluating the economic impacts of carbon mitigation policies. Taking Italy as an example, we find that the estimation for carbon price and the economic cost of a de-carbonization pathway by means of a model with technological and regional details can be lower than a model without such details by up to $40 \%$. Additionally, the effect of representing regional details appears to be far more important than the effect of representing the details of electricity technology in both the estimated carbon prices and the estimated economic impacts. Our results for Italy highlight the importance of modeling uncertainties of these two key assumptions, which should be appropriately acknowledged when applying CGE models for policy impact assessment. Our conclusions can be generalized to different countries and policy scenarios not in terms of absolute numbers but in terms of economic explanations. In particular, intra-national trade and the sub-national sectoral/technological specialization are important variables for understanding the economic dynamics behind these outcomes.
\end{abstract}

Keywords: Computable General Equilibrium, Carbon Mitigation Policy, Sensitivity, Technology, Sub-national regions

\footnotetext{
${ }^{\mathrm{a}} \mathrm{CMCC}$ - EuroMediterranean Center on Climate Change

${ }^{\mathrm{b}}$ FEEM - Fondazione Eni Enrico Mattei

${ }^{\mathrm{c}}$ CSIRO - Commonwealth Scientific and Industrial Research Organization

${ }^{\mathrm{d}}$ CAMA - Centre for Applied Macroeconomic Analysis, Australian National University

${ }^{\mathrm{e}}$ Department of Energy and Environment, Chalmers University of Technology

*Corresponding author, Email: gabriele.standardi@feem.it
}

This is a pre-print version of Gabriele Standardi, Yiyong Cai and Sonia Yeh, Sensitivity of Modeling Results to Technological and Regional Details: The Case of Italy's Carbon Mitigation Policy, Energy Economics, ISSN 0140-9883, http://dx.doi.org/10.1016/j.eneco.2017.01.021 


\section{Introduction}

On account of human activity, the atmospheric concentration of greenhouse gases (GHG) has substantially increased since the Industrial Revolution. This is believed to be one of the key contributing factors of climate change (IPCC, 2014a). To mitigate the potential negative impacts of climate change, the European Union (EU) has put in place ambitious policies to control GHG emissions, develop renewable energies and improve energy efficiencies, with the aim of reducing emissions by 40\% from the 1990 level by the end of 2030 (European Council, 2014). To achieve this, the existing reduction target of $1.74 \%$ per year for $2015-2020$ will need to be scaled up to $2.2 \%$ per year from 2021 (European Council, 2014). Various studies suggest that significant reforms are needed to ensure the effectiveness of EU-internal abatement by 2030. This includes restoring a higher price path to the anticipated $€ 30$ or higher, as compared to the current level of around $€ 5$ per ton of CO2-equivalent (CO2e) since 2013 (Brink et al., 2014; Hu et al., 2015).

The European target is now part of the legally binding global agreement adopted at the Paris Conference (COP21) in December 2015 to limit global warming to well below $2^{\circ} \mathrm{C}$ (FCCC, 2015; the Latvian Presidency of the Council of the European Union, 2015). Under the agreement, 188 countries representing 98\% of global emission have made their Intended Nationally Determined Contribution (INDC). Among these countries are the most important economic players such as the United States, China, the European Union, Russia and India. The INDCs include both adaptation and mitigation actions. These actions will entail a reduction of GHG emissions, and at a certain point in time the transition toward green technologies and presumably some carbon pricing.

Imposing a higher carbon price will increase the overall cost of fossil-based energies. As a result, producers will switch to less carbon-intensive technologies and practices such as energy conservation, while consumers will shift to goods and services with lower embodied emissions or reduce demand. The transition requires investments in new infrastructures, altered patterns of resource use, and shifts in labor markets. High transition costs can be associated with an ambitious de-carbonization target such as those committed by the EU. The debate on the costs of climate change mitigation implies very sensitive political considerations on distributional impacts among regions and industries (Gough, 2013; Barrett et al., 2015), and such discussions need to be based on rigorous quantitative analyses. In this context, Computable General Equilibrium (CGE) modeling has been a popular tool for analyzing the economic impacts of national carbon mitigation policies. The modeling approach captures the interactions between supply, demand, prices, labor, capital and trade; and it therefore provides a rigorous and consistent evaluation framework to quantify the 
socioeconomic impacts of government policies on energy production and consumption as well as other related economic activities. By identifying the winners and losers among affected regions, sectors, institutions and technologies, CGE models can help policy makers gain a balanced view of the consequences of their decisions.

However, results from CGE models vary greatly, and they are sometimes contradictory, even for a common scenario setting. For instance, five recent studies suggest that for the EU27 countries to achieve a $20 \%$ emission reduction target by 2020 from the 1990 level, the carbon price can range from $19 € / \mathrm{tCO} 2$ to $70 € / \mathrm{tCO} 2$ (Bohringer et al., 2009; Durand-Lasserve et al., 2010; Peterson et al., 2011; Bosello et al., 2013; Orecchia and Parrado, 2013). These results indicate that there could be gross domestic product (GDP) gains of around $0.1 \%$ or losses of up to $2 \%$. Similarly, Pearce (2012) finds that for Australia to achieve a 15\% emission reduction target by 2020 from the 2000 level, the national carbon price is estimated to be from $25 \$$ to $70 \$$ per ton of $\mathrm{CO} 2$, according to a metaanalysis of different CGE models, including G-Cubed (McKibbin et al., 2010), GTEM (Commonwealth of Australia, 2008 and 2011), and the Tasman Global Model (ACIL Tasman, 2008). The consequential GDP losses are estimated to be $0.4 \%$ to $1.4 \%$ from the business as usual.

Great variations in modeling results are not surprising, and numerous modeling comparison efforts have been conducted since the 1970s to explore the underlying factors contributing to the differences and to gain insights (e.g. some more recent efforts include Luderer et al. (2012), IPCC (2014b), and Fawcett et al. (2014)). Most of the differences in modeling results can be attributed to differences in (1) modeling mechanisms (e.g. macroeconomic "top-down" model vs. "bottom-up" technology-detailed optimization model), (2) the scale and scope of the model (e.g. the boundary and resolution of the analysis), (3) assumptions about baseline scenarios, and (4) assumptions on policy constraints (Pearce, 2012), and market responses (Carraro et al., 2012).

Among these factors, the model differences in technological and geographical details are particularly noticeable, even though their contributions to uncertainties have not been systematically quantified in the climate policy literature. As an example, studies examining the $20 \%$ emission reduction target by 2020 in EU27 show different levels of sophistication in representing the electrical sector and country-level details. The ICES model (Bosello et al., 2013; Orecchia and Parrado, 2013) has four electricity technologies, including hydro, solar, wind and others, whereas the models used in other studies have only one electricity sector without further technological details. Peterson et al. (2011) considers EU27 as a single economic unit, while the models in other 
studies account for each major country separately. In the Australian case study referenced above, while the GTEM model (Commonwealth of Australia, 2008 and 2011) and the Tasman Global model (ACIL Tasman, 2008) disaggregate the electricity sector into a menu of technologies with different cost structures and carbon intensities, the G-Cubed model (McKibbin et al., 2010) represents the production of electricity as a single technology. Similarly, the Tasman Global model considers each Australian state and territory as a single economic unit, whereas G-Cubed and GTEM do not account for the sub-national differences.

Given the great differences in the cost and emission profiles of electricity generation technologies, there will be variations in the represented electricity sector responses to shocks such as policy changes. For example, the average levelized cost of electricity (LCOE) for a conventional coal power plant is much lower than that of a solar unit (EIA, 2014). Furthermore, nations with politicoeconomic union or administrative units within a nation are heterogeneous in their socioeconomic characteristics. Each region can be affected differently by a given policy shock. Whether or not models take into account these technological and regional details can affect model ability and the degree of the response to policies such as a carbon tax, leading to a great difference in the assessment of the economic impacts of policies. Nevertheless, the importance of model differences in the assumptions of technological and regional details have not been clearly communicated or analytically examined, making it difficult to place results on a comparable basis and put forward insights and policy recommendations.

It is the aim of this paper to carry out a systematic assessment of the sensitivity of CGE models to the assumptions of technological and geographical scales. We use Italy, the fourth largest economy and third carbon emitter in the EU, as a case study, and investigate the robustness of simulation results for a national carbon mitigation policy by varying the models' technological and regional details. We start with a basic version of a global CGE model and database, which considers Italy as a single economic unit with one technology in the electricity sector. We then disaggregate the electricity sector into a bundle of various generation technologies, and split Italy into 20 subnational regions to create more spatially disaggregated versions of the model. The comparison across different model specifications enables us to quantify the importance of technological and regional disaggregation in response to a given policy by carefully laying out the causal inferences that drive the differences of results. It also allows us to quantitatively assess the impacts on modelling results within the realm of the climate policies that we examined in this study. To the 
best of our knowledge, this is the first study to quantify the importance of technological and regional details in the CGE modeling of carbon mitigation policies.

The paper is organized as follows. In section 2 we present the economic and energy landscape of the Italian regions. In section 3 we describe the methodology for increasing the technological and geographical resolution of a CGE model, and set out the experiment design. In section 4 we discuss results and provide an economic interpretation. We conclude in Section 5 and offer our insights, caveats and suggestions for future studies.

\section{The economic and energy landscape of the Italian regions}

As already mentioned, the purpose of the paper is to carry out a systematic assessment on the sensitivity of CGE models to the assumptions of technological and geographical details. The Italian case study is particularly interesting as Italy is characterized by a great deal of heterogeneity at the socio-economic and technological-energy level. Overall, the country can be split into Northern, Central and Southern regions, as displayed in Figure 1.

Figure 1: Map of Italian regions

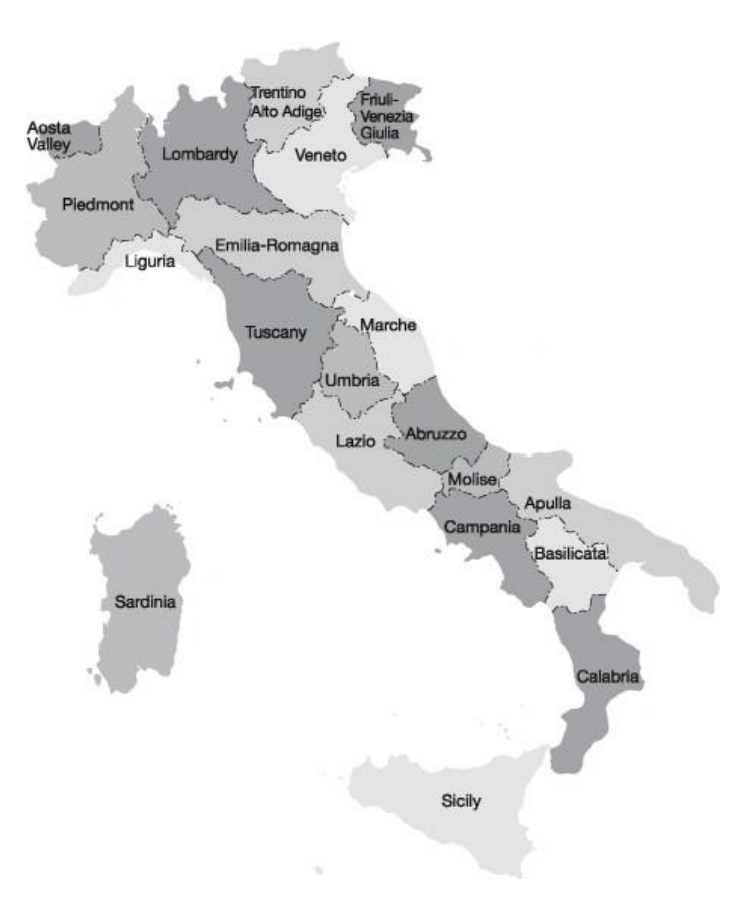

\section{Legend}

\begin{tabular}{|c|c|}
\hline Piedmont & \multirow{8}{*}{$\begin{array}{l}\text { Northern } \\
\text { regions }\end{array}$} \\
\hline Aosta Valley & \\
\hline Lombardy & \\
\hline Trentino Alto Adige & \\
\hline Veneto & \\
\hline Friuli Venezia Giulia & \\
\hline Liguria & \\
\hline Emilia-Romagna & \\
\hline Tuscany & \multirow{4}{*}{ Central regions } \\
\hline Umbria & \\
\hline Marche & \\
\hline Lazio & \\
\hline Abruzzo & \multirow{8}{*}{$\begin{array}{l}\text { Southern } \\
\text { regions }\end{array}$} \\
\hline Molise & \\
\hline Campania & \\
\hline Apulia & \\
\hline Basilicata & \\
\hline Calabria & \\
\hline Sicily & \\
\hline Sardinia & \\
\hline
\end{tabular}

The demographic composition in Figure 2 shows that Lombardy in the North has the largest population. Campania and Sicily in the South and Lazio in the Center are also relatively populous, 
representing 9.6\%, 8.3\% and 9.5\% of the Italian population, respectively. Strong economic disparities can be observed within the Italian territory. The North is richer than the South in per capita terms (Figure 2). Despite a huge deindustrialization process under way since 2008 in the aftermath of the global financial crisis, the Northern regions on average are still more specialized in manufactures (Figure 3). In contrast, the Southern regions are slightly more reliant on agriculture; and the central regions are mixed, with Lazio exhibiting a strong specialization in services, in particular public services for its role as the region hosting the capital Rome.

Figure 2: Population and GDP per capita in 2011 of the Italian regions

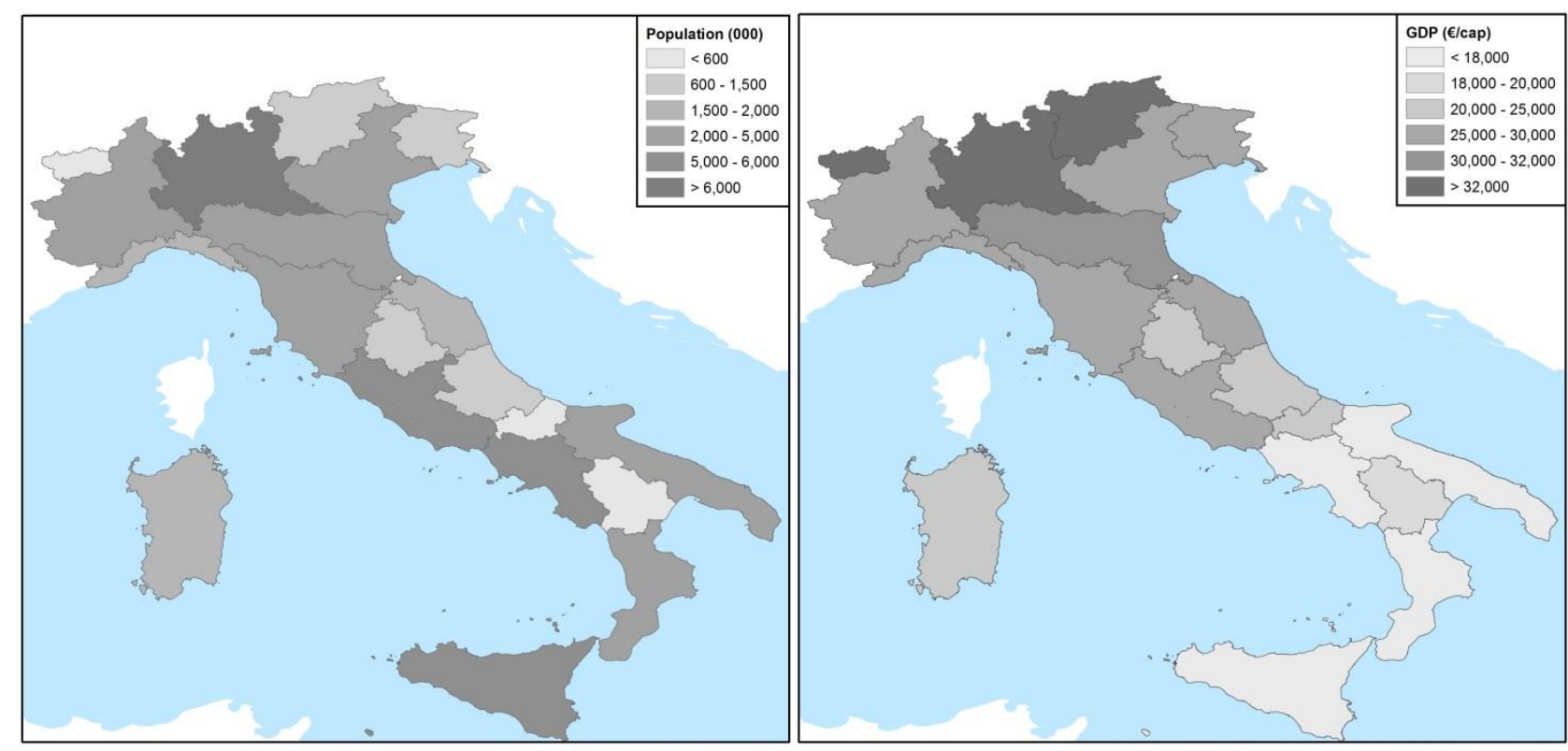

Source: Italian Statistical Office (ISTAT). 
Figure 3: GDP shares and sectoral shares of the Italian regions in 2011

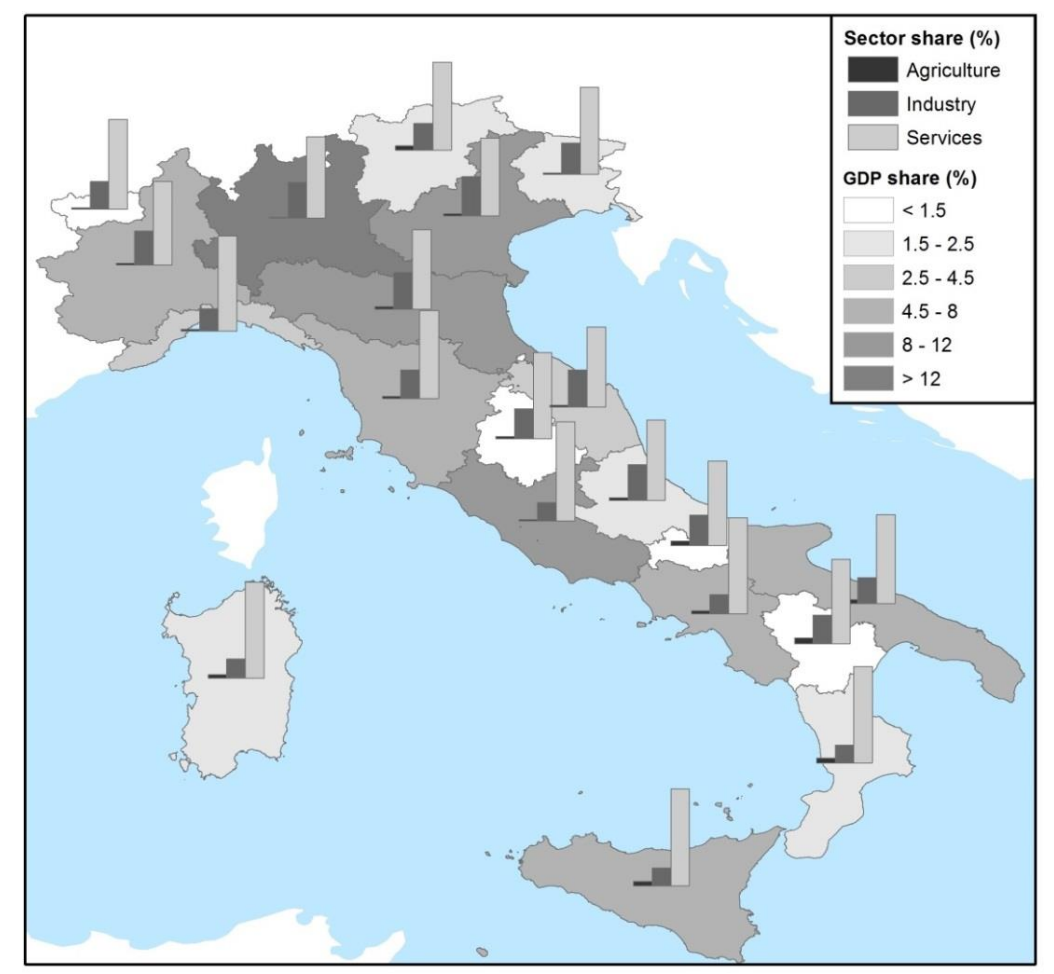

Source: Italian Statistical Office (ISTAT).

The primary energy supply in Italy "is heavily dependent on imports" of coal, oil and gas from abroad $^{1}$. Figure 4 shows how the supply is distributed across the regions. Oil and gas prevail in all the regions except Liguria and Apulia, where coal is still dominant. The energy intensive Northern economies of Lombardy, Emilia-Romagna, Piedmont and Veneto show the highest values of energy supply in million tons of oil equivalent (Mtoe). In the South, Sicily also exhibits high numbers because of its important role in the refining of petroleum imports.

\footnotetext{
${ }^{1}$ Source: https://www.eia.gov/beta/international/country.cfm?iso=ITA.
} 
Figure 4: Primary Energy Supply in 2008 and Power Generation of the Italian Regions in 2013
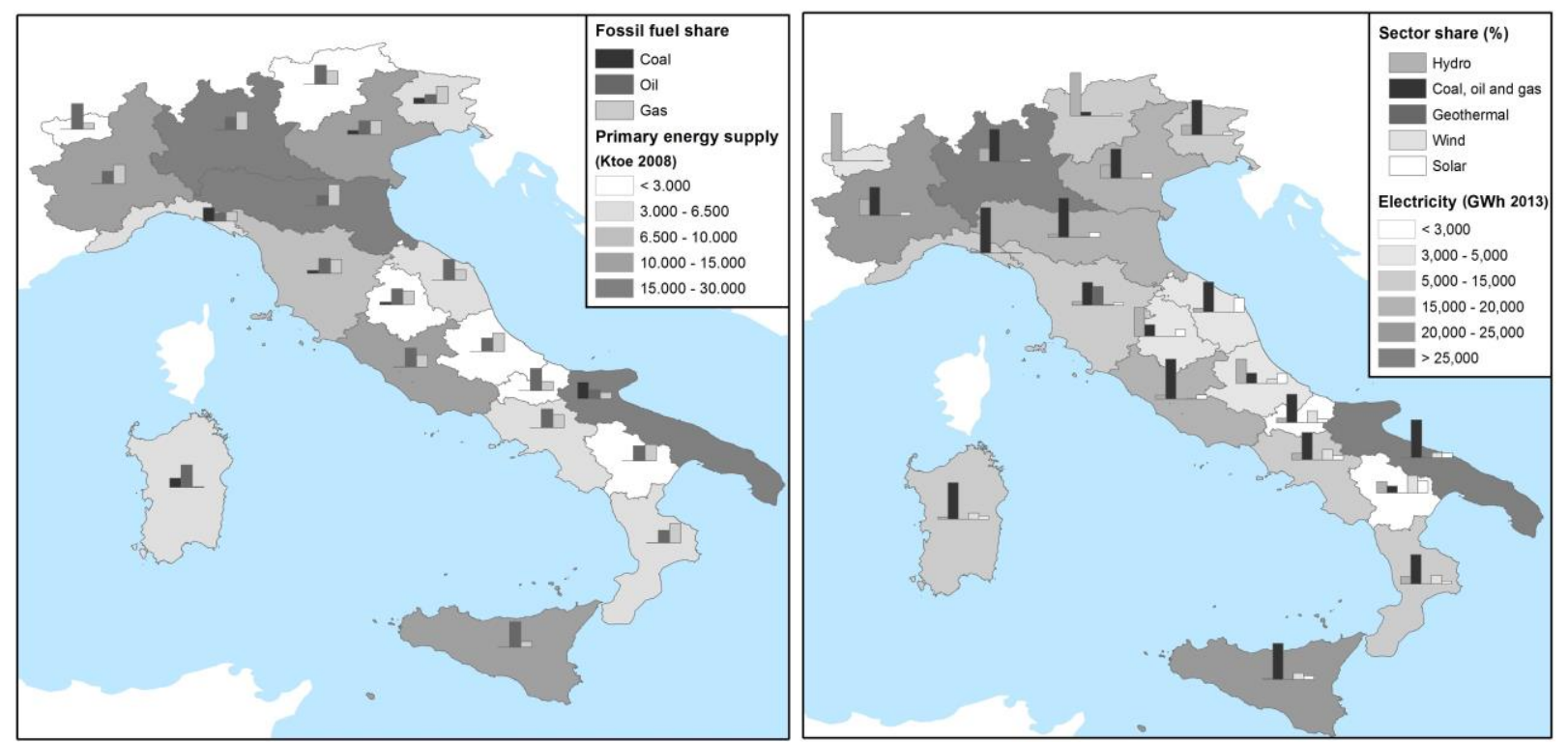

Source: Ente per le Nuove tecnologie, l'Energia e l'Ambiente (ENEA) for the primary energy supply, and Trasmissione Elettrica Rete Nazionale (TERNA) for the electricity mix.

Figure 4 also shows the electricity generation mix $^{2}$. Fossil fuels prevail in most Italian regions except the Southern ones (Abruzzo and Basilicata), the Central ones (Tuscany and Umbria) and the Alpine regions Trentino and Aosta Valley, where there are large shares of hydroelectricity. In general, wind electricity plays a non-negligible role in the South because of favorable climatic conditions. Solar electricity is becoming more and more important in some regions of the CenterSouth, including Umbria, Marche, Abruzzo and Basilicata. It is worth noting that the situation is still evolving and the time-series data show a substantial variability ${ }^{3}$. These sectors are relatively new and the technologies are likely to change rapidly in the next few years.

Tuscany is unique in the Italian panorama for renewables. Taking advantage of its geothermal resources, this region has highly developed geothermal power technology. In the South, Apulia, Sicily and Sardinia are fossil-fuel intensive in electricity generation. The scarcity of water basins makes hydroelectricity almost entirely absent in these regions. Solar and wind technologies only partially compensate for this gap. Basilicata has the largest oil reserve in Europe but during the last decade it has seen a rapid growth of solar and wind technologies, generating, together with hydro, more than three quarters of its electricity production.

\footnotetext{
${ }^{2}$ Figure 4 presents recent data from Trasmissione Elettrica Rete Nazionale (TERNA) on the electricity mix (http://download.terna.it/terna/0000/0113/40.pdf). TERNA does not provide information on biomass and waste. We use data from Ente per le Nuove tecnologie, l'Energia e l'Ambiente (ENEA) for the year 2008 to include these two technologies in the CGE model (Catoni and Iorio, 2011).

${ }^{3} \mathrm{https} / / / \mathrm{www}$. terna.it/it-it/sistemaelettrico/statisticheeprevisioni/datistatistici.aspx.
} 
The gaps between regions are even more pronounced as regards energy consumption (see Figure $5)^{4}$. This is largely driven by the sectoral specialization across regions, as we have discussed above. Overall, energy consumption (electricity included) is greater in the Northern regions, which have more industries, than in the Southern ones. In absolute terms, Lombardy consumes the highest level of energy. However, some exceptions exist. For example, Apulia in the South has a strong industrial energy consumption because of the presence of refineries and steel mills.

Transportation is also an important driver of energy consumption. For instance, Trentino Alto Adige, Aosta Valley and Liguria in the North consume a higher share of energy from transport. Similarly, Lazio, Campania, Sicily and Sardinia in the Center and the South also see a large share of energy consumption (38-47\%) by the transportation sector.

Energy consumption in the residential sector is the result of a combination of economic, technological and geographical factors, all of which interact and contribute to the total amount of consumption. For example, the colder Northern regions consume more energy for heating during the winter, while the warmer Southern regions consume more energy during the summer for airconditioning. Physical morphology also matters (mountainous or flat regions) together with different levels of energy efficiency. Figure 4 shows that the Northern Alpine region of Trentino Alto Adige and the flat Southern region of Apulia have the highest and lowest shares of their energy consumption in the residential sector.

Ultimately, emissions (Figure 5) reflect the pattern of energy supply and demand profiles discussed above. For instance, hydropower covers a very high share of electricity in the Alpine regions of Trentino Alto Adige and Aosta Valley. This explains the very low shares of emissions in the electrical sector for these two regions. Conversely, Liguria is fossil-fuels intensive and shows the highest share of emissions.

Because of these technological and socio-economic differences, it is reasonable to anticipate variations in the responses of the Italian regions to a carbon tax.

\footnotetext{
${ }^{4}$ Both data for energy consumption and emissions at the regional level stem from ENEA, Catoni and Iorio (2011) and Mancuso (2010), respectively.
} 
Figure 5: Energy Consumption in 2008 and CO2 Emissions in 2006 of the Italian Regions

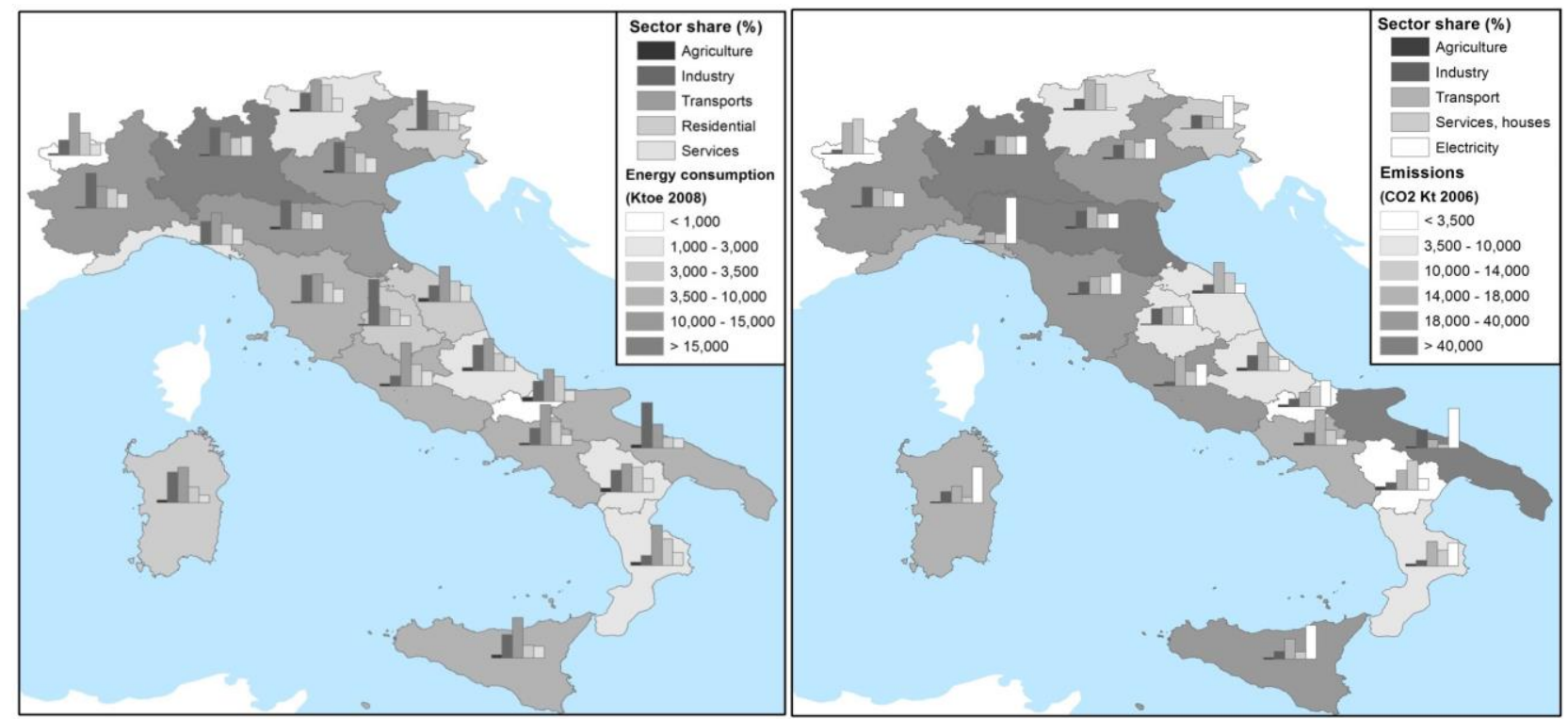

Source: Ente per le Nuove tecnologie, l'Energia e l'Ambiente (ENEA)

\section{Methodology for detailing the technological and geographical characteristics in CGE modeling}

\subsection{General characteristics of CGE models}

A typical CGE model has a neo-classical economic structure (e.g. Hertel, 1997). The world economy is disaggregated into a set of regions. Each region has a representative household that maximizes the consumption utility flow subject to a budget constraint. Within a region, each sector has a representative firm minimizing costs subject to an output constraint. Households own and supply factor inputs of production, which include capital, labor, land and natural resources. Payments by the firms to all factor inputs are received by the households, and these are in turn spent on purchasing commodities produced by the firms. The regions interact with each other through trade, as regional households consume both domestic and imported goods. Capital investments take place across regions, therefore households can allocate their savings either domestically or internationally. In contrast, factor inputs of production are available only domestically. The factor and commodity markets are in equilibrium, as prices adjust to balance supply and demand. By construction, a CGE model is a market-based tool; and the introduction of a tax is usually equivalent to a market distortion, leading to welfare $\operatorname{loss}^{5}$.

\footnotetext{
${ }^{5}$ Traditional CGE models do not account for the environmental benefits of climate change mitigation resulting from a carbon price or equivalently a carbon tax. When these benefits are internalized in an integrated modeling framework, a carbon price/tax can lead to welfare gains (see, e.g., Cai et al. (2015)).
} 
Our starting point is the CTAP model developed by Cai and Arora (2015), which is a variant of the neo-classical CGE model Global Trade Analysis Project (GTAP) (Hertel, 1997). GTAP is calibrated to the GTAP 8 database (Narayanan et al., 2012), a series of SAMs (Social Accounting Matrixes) for a maximum number of 129 countries or groups of countries (among them Italy), and 57 sectors covering all the economic system for the year 2007. A SAM is a description of a country's supply and use table, containing details of sectors, activities, commodities, institutions and capital accounts (Miller and Blair, 2009). It is the key matrix that measures distributional impacts of policy stimulations.

\subsection{Disaggregating electricity technologies: from CTAP-1 to CTEM-1}

The CTAP model considers the electricity sector as characterized by a unique technology. This technology (Figure 6) is a Leontief function between power generation and non-fuel intermediates inputs involved in the O\&M and distribution activities. In addition, generation technology allows substitution by means of a CES (Constant Elasticity Substitution) function between the bundle of primary factors (capital, labor and a fixed factor specific to the technology) and the bundle of fossil fuel intermediates (oil, coal and gas). As seen in the figure, imposing a carbon price will result in a shift toward higher share costs of labor and capital, and less oil, coal and gas, mimicking the transition toward cleaner technologies.

Figure 6: Electricity generation in CTAP

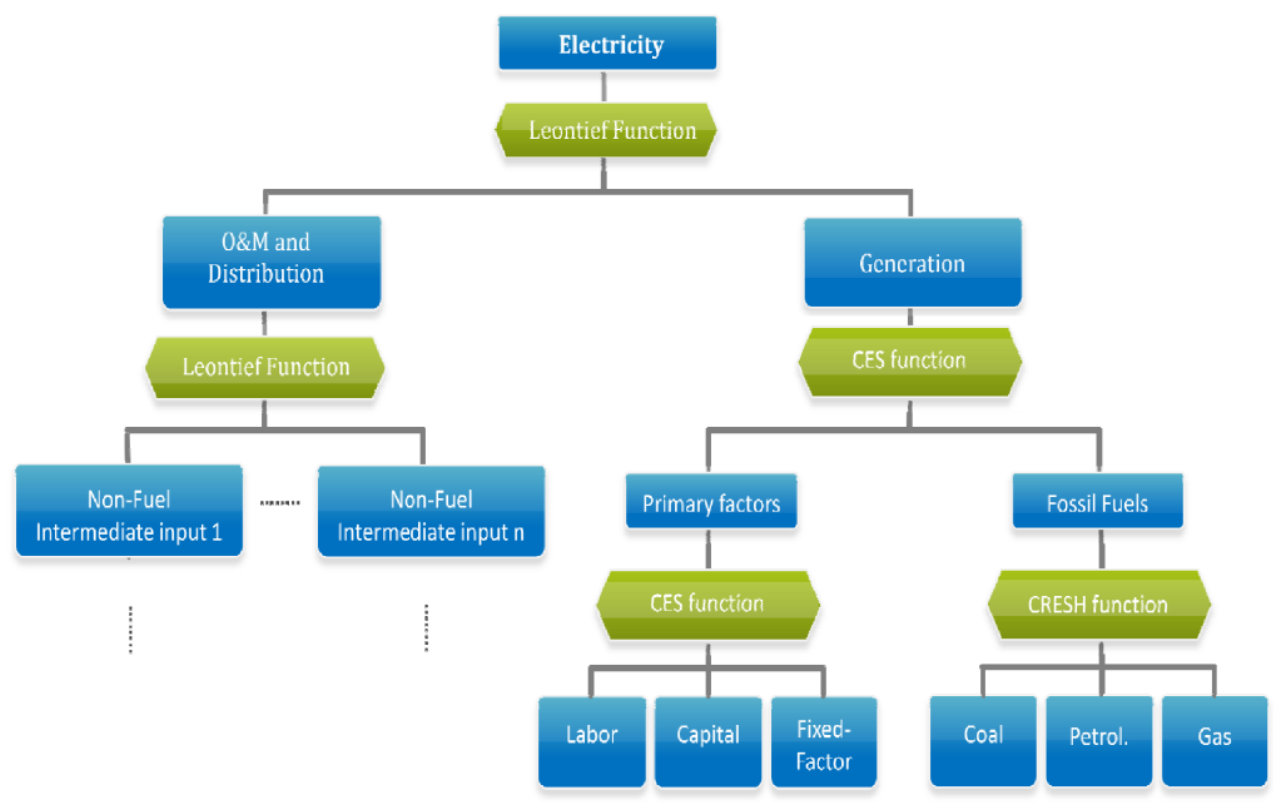


The CTEM model ${ }^{6}$ (Cai and Arora, 2015; Cai et al, 2015) is otherwise identical to CTAP but uses an electricity technology bundle (Figure 7). The CTEM model features disaggregated modeling of the electricity sector into a bundle of 13 generation technologies (Coal, Oil, Gas, Nuclear, Hydro, Wind, Solar, Biomass, Waste, Geothermal, Coal plus CCS, Oil plus CCS, Gas plus CCS). Competing electricity technologies are combined through the CRESH (Constant Ratios of Elasticities of Substitution, Homothetic) function (see Hanoch, 1971; Pant, 2007; Cai and Arora, 2015), which allows for differing levels of substitution between any two technologies.

The structure of each technology in CTEM is represented in Figure 8. Perfect complementarity is assumed between the bundle of primary factors and the technology-specific intermediate inputs. For instance in the case of fossil fuel technologies the intermediate inputs are coal, oil or gas while renewable technologies use different intermediate goods such as agricultural feedstock to produce biomass for electricity generation.

In both models, commodity-embedded flows of energy and $\mathrm{GHG}$ emissions $\left(\mathrm{CO}_{2}, \mathrm{~N}_{2} \mathrm{O}, \mathrm{CH}_{4}\right.$ and Fgases) are calculated based on the economic values of the SAM. To build these SAMs, both CTEM and CTAP are calibrated to the GTAP 8 database and other available data from the IEA (International Energy Agency) and EIA (Energy Information Administration) (EIA, 2012 and 2013).

In this first step of our methodology, we create two basic models, CTAP-1 and CTEM-1. Each model is represented by 3 regions (Italy, Rest of Europe and Rest of the World) and 19 sectors (among them the electricity sector) (Table 1). The reference year is 2007. CTEM-1 has greater technology details for the electricity sector (as shown in Figure 7), and is otherwise identical to CTAP-1. The comparisons between the CTAP-1 and CTEM-1 models allow us to investigate the impacts of modeling electricity production as a single production technology (Figure 6) vs. 13 generation technologies (Figure 7).

\footnotetext{
${ }^{6}$ In the paper of Cai et al. (2015) CTEM is referred to as GTEM-C. GTEM (Global Trade and Environment Model) was developed by Pant (2007). GTEM-C has added new features in both model and database. The letter C refers to the Australian research institute CSIRO (Commonwealth Scientific and Industrial Research Organization), whose team has upgraded the original GTEM model.
} 
Figure 7: Electricity generation in CTEM

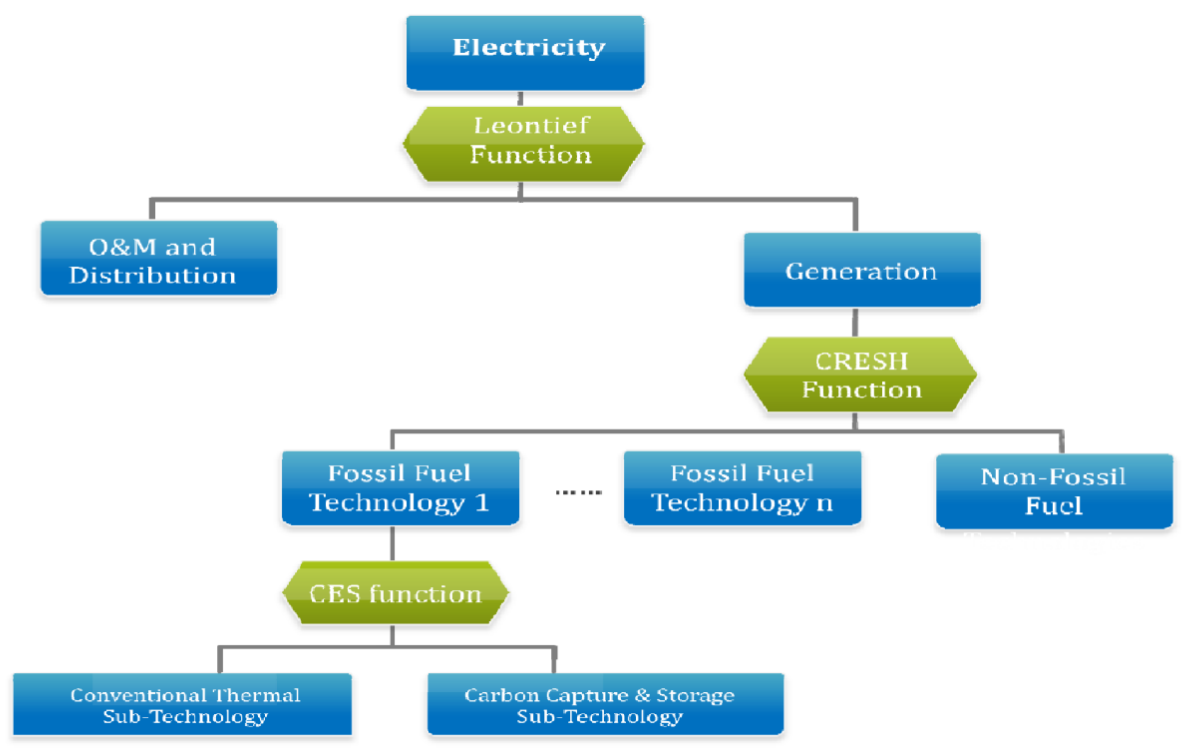

Figure 8: Technology in CTEM

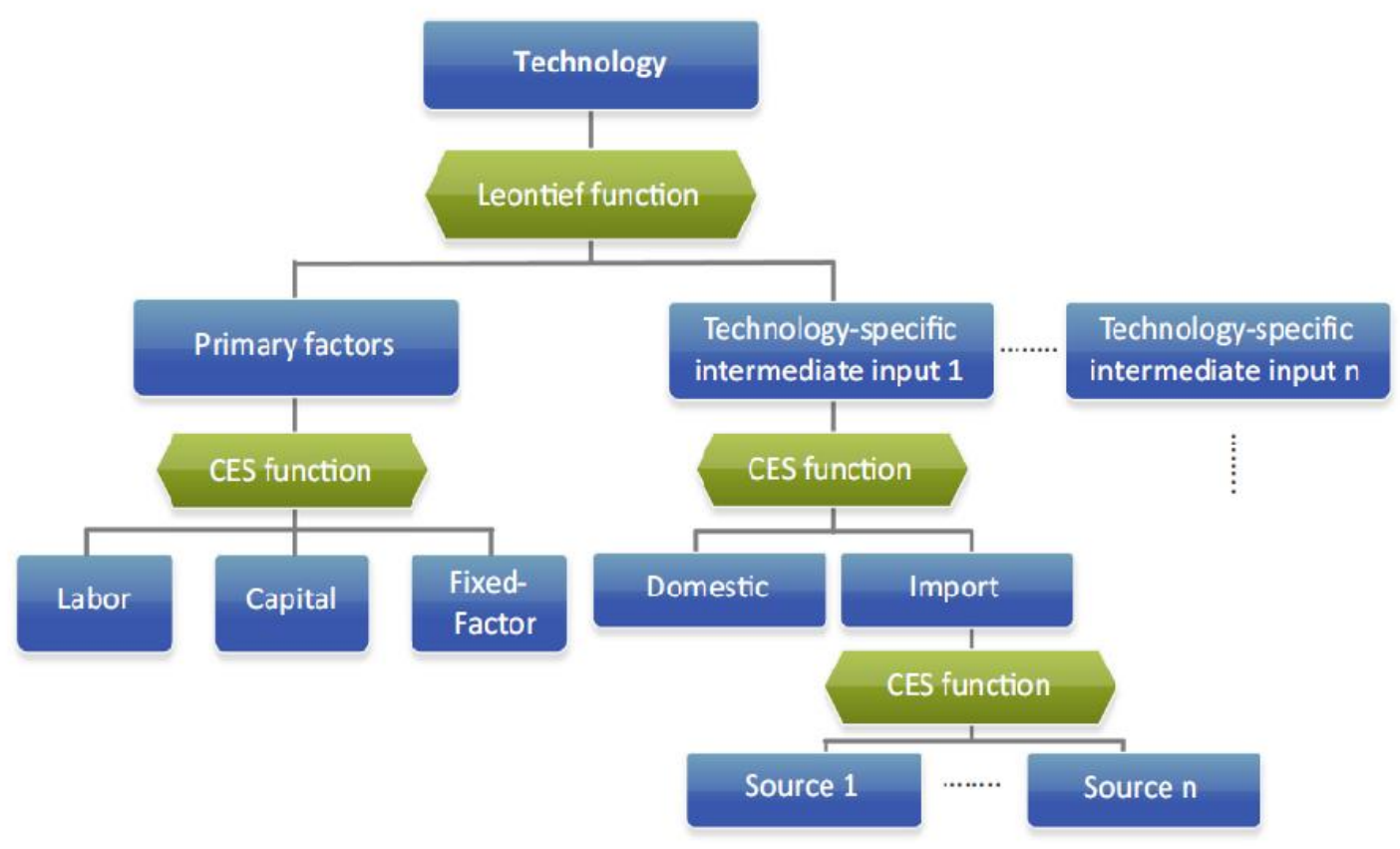


Table 1: Sectors in CTAP and CTEM

\begin{tabular}{|c|l|c|l|}
\hline COL & coal & MANU & Manufactures \\
\hline OIL & oil & OTP & Land transport \\
\hline GAS & gas & WTP & Water Transport \\
\hline P_C & coal and oil products & ATP & Air transport \\
\hline ELY & electricity & CROPS & Crops \\
\hline I_S & Iron and Steel & LSTK & Livestock \\
\hline NFM & Nonferrous metals & FISHFOR & Fishing and Forestry \\
\hline CRP & Chemical, rubber, plastic products & FOOD & Processed Food \\
\hline OMN & Other mining & SVCE & Services \\
\hline NMM & Nonmetallic minerals & & \\
\hline
\end{tabular}

\subsection{Creating the sub-national database: from CTAP-1 to CTAP-20}

To further investigate the impacts of modeling sub-national details, we disaggregate Italy in 20 subnational regions, moving from CTAP-1 to CTAP-20. To achieve this goal, we need to split Italy in the GTAP 8 database into 20 regions, keeping the consistency of all economic accounts in the SAM.

The first step consists of disaggregating production, originally available at the country level, to the regional scale. First, we match the ISTAT (Italian Statistical Office) sectors with the 57 GTAP sectors. Then the regional shares of value added, labor and land computed from the ISTAT data are used to distribute the respective GTAP Italian data across the 20 Italian regions (ISTAT Agricoltura e Zootecnia, ISTAT Conti Economici Regionali, ISTAT Valore Aggiunto ai Prezzi di Base dell'Agricoltura per Regione). For the two other factor inputs that only appear in the GTAP database, capital and natural resources, the respective regional shares are not retrievable from ISTAT. Those of capital are computed as a difference between value added and labor from the ISTAT data, while those of natural resources are proxied by the sub-national share of value added in fishery, forestry and mining sectors. Then we split the international trade of the sub-national regions by using information from ISTAT and ICE (Istituto Nazionale per il Commercio Estero) (2008).

The final step, consisting in the determination of domestic regional demand and bilateral trade flows between sub-national regions, is the most challenging. These data are very often missing. To overcome the problem, the procedure usually adopted is the so-called gravitational approach as in 
Wittwer and Horridge (2010) and Dixon et al. (2012). By this method, the bilateral intra-country trade flows are estimated by using a gravity equation, as in Newtonian physics. This accounts for sectoral production in the origin region and sectoral demand in the destination region, as attractors, and the distance between them as friction. Some alternative approaches exist. For example, Chintrakarn and Millimet (2006), and Canning and Tsigas (2000) use transport data for the United States to obtain trade flows across member States. Dubé and Lemelin (2005) also use transport data to estimate the trade flows across the three sub-national regions of Quebec. In addition, they integrate this information with economic data about aggregate sub-national exports and imports, and apply a cross-entropy optimization method to make the two types of information consistent.

Following Dubé and Lemelin (2005), we derive the domestic regional demand and the trade flows across sub-national regions by using the already cited ISTAT economic production data and ISTAT transportation data (ISTAT Trasporto Merci su Strada 2008-2009, ISTAT Trasporto Aereo 20032009, ISTAT Trasporto Marittimo 2005-2008, ISTAT Trasporto Ferroviario 2004-2009). To reconcile the transportation and economic data, we further implement the RAS statistical method (Deming and Stephan, 1940; Bacharach, 1970). For a detailed description of the methodology, readers can refer to Standardi et al. (2014) and Carrera et al. (2015).

To obtain their emissions, we assume that all Italian regions have the same emissions intensity for the same energy input in the same sector. As a result, emissions are proportional to the economic variables in the database. In particular, we use the ratio of a regional variable to the sum of all Italian regions, multiplied by the corresponding variable for Italy as a whole in the GTAP CO2 and non-CO2 databases.

It is worth noting that CTAP-1 and CTAP-20 models have exactly the same model specifications. This means that we have the same equations, variables and parameters. The only difference is the database. CTAP-20 considers 20 Italian regions in place of considering Italy as a whole in CTAP-1.

\subsection{Combining the technological and regional details: from CTAP-20 to CTEM-20}

In this step of the process, we include both the technological and geographical details in the model. We construct a regional database of power generation from fossil fuels and renewable resources in Italy that is consistent with the IEA World Energy Balance Table (2013). We also use further information from TERNA ${ }^{7}$ and ENEA (Catoni and Iorio, 2011) to integrate the national and sub-

\footnotetext{
${ }^{7}$ Source: http://download.terna.it/terna/0000/0113/50.pdf
} 
national data for electricity in Italy. In particular, the information from ENEA allows us to build a more detailed database for renewables in each one of the Italian regions. Solar, wind, geothermal, waste, biomass and hydro power technologies are considered.

These steps create a model with a technology bundle in the electricity sector within each Italian region. The model, which we now call CTEM-20, has the same technologies as CTEM-1 for the electricity sector. Like CTAP-1 and CTAP-20, CTEM-1 and CTEM-20 have exactly the same model specifications but use a different database.

\subsection{Accounting for labor mobility within Italy: CTEM-20Lab}

When constructing CTAP-20 and CTEM-20, we have followed standard country-level CGE models, which exclude the possibility for inter-national migration (e.g., Hertel (1997)). This means ruling out inter-regional migration in CTAP-20 and CTEM-20. However, we note that workers are likely to move between regions of the country. To further test the importance of labor mobility in modeling, we have created an extension of CTEM-20, which is called CTEM-20Lab. This model allows for labor mobility within Italy, by using a CET (Constant Elasticity Transformation) function to determine the endogenous supply of labor at the regional level. Workers migrate according to the relative differentials of wage between Italian regions, while respecting the national constraint of labor supply. The degree of intra-national labor mobility is regulated by the elasticity of substitution in the CET function. When its value is zero workers cannot move outside the region; and when its value tends to infinite we have perfect labor mobility within Italy. In this exercise, we have set an intermediate value (2.0) which corresponds to an imperfect labor mobility between Italian regions (see Standardi et al. (2014) and Carrera et al. (2015).).

\section{Results}

With the five versions of the CGE model, we have carried out a simple comparative static exercise. We use 2007 data as our baseline, and simulate a counter-factual scenario in which a $20 \% \mathrm{CO} 2$ emission reduction target in Italy is achieved through a uniform national carbon tax. Even if this target is consistent with the five recent studies for EU27 (Bohringer et al., 2009; Durand-Lasserve et al., 2010; Peterson et al., 2011, Bosello et al, 2013, Orecchia and Parrado, 2013), a comparison is not possible. First of all, unlike the five previously cited studies, no permits trade or technological advancement in energy saving is assumed in this paper. In addition, the climate policy is implemented only in Italy. Therefore, our exercise will lead to higher estimations of carbon prices 
for the $20 \%$ mitigation target. Readers should not take our results as a prediction about future policies and economic consequences.

Our primary objective is to test the sensitivity of the model. By moving from CTAP-1 to CTEM20Lab we are able to test how the different assumptions introduced step by step in the model affect the results for the mitigation costs, and to keep track of all changes in a systematic and controlled way. In particular, we can disentangle the technological and spatial component and look at their interaction. We start with the one-region and one-electric-technology model (CTAP-1), to the disaggregated 20-region and 13-electric-technology model (CTEM-20), and finally one that accounts for labor mobility between regions (CTEM-20Lab). We report the results below.

\subsection{Carbon price and the overall economy}

Table 2 shows the simulation results for carbon price of the five models. We find that, as more details of technological and spatial dimension are added to the modeling, the estimates for carbon price in Italy monotonically decrease. The effect of representing regional details $(-28.8 \%)$ appears to be twice as large as the effect of representing the details of electricity technology (-14.9\%). Including both regional and technological details together will lower the estimate for carbon price by $-40.4 \%$; but further addition to labor mobility appears to have only a marginal effect on reducing the estimate.

Table 2: Carbon price to achieve a 20\% national CO2 emission reduction in Italy and the estimated effects of disaggregating regions and electric technologies

\begin{tabular}{|l|c|c|c|c|}
\hline & \$ per ton of CO2 & $\begin{array}{c}\text { Effect of tech } \\
\text { disaggregation }\end{array}$ & $\begin{array}{c}\text { Effect of regional } \\
\text { disaggregation }\end{array}$ & $\begin{array}{c}\text { Effect of adding } \\
\text { labor mobility }\end{array}$ \\
\hline CTAP-1 & 208 & $-14.9 \%$ & & \\
\hline CTEM-1 & 177 & & $-28.8 \%$ & \\
\hline CTAP-20 & 148 & \multicolumn{2}{|c|}{$-40.4 \%$} & \\
\hline CTEM-20 & 124 & \multicolumn{2}{|c|}{$-40.9 \%$} & \\
\hline CTEM-20Lab & 123 &
\end{tabular}

As a result of the different estimates for carbon price, the five models arrive at different predictions for mitigation costs as measured by GDP loss from the 2007 level (Table 3). Overall, the model that entails the most regional and technological details plus assumptions of labor movement between regions (CTEM-20Lab) shows much lower estimate of abatement cost (approximately -41\%) than 
the one that does not account for the regional and technological differences (CTAP-1). While the impact of representing electric technological details is less significant $(-1.3 \%)$ than that of representing regional details $(-22.6 \%)$ when considered separately, the interaction of them are substantial leading to $33.7 \%$ reduction in the estimate of mitigation cost. Taking account of labor mobility among regions will further reduce the estimated cost by $41.2 \%$. The regional details are also reported in Table A.1 of the appendix.

Table 3: Mitigation cost to achieve a 20\% national CO2 emission reduction in Italy and the estimated effects of disaggregating regions and electric technologies

\begin{tabular}{|l|c|c|c|c|}
\hline & $\begin{array}{c}\text { GDP loss } \\
\text { (in 2007 billion US\$) }\end{array}$ & $\begin{array}{c}\text { Effect of tech } \\
\text { disaggregation }\end{array}$ & $\begin{array}{c}\text { Effect of regional } \\
\text { disaggregation }\end{array}$ & $\begin{array}{c}\text { Effect of adding } \\
\text { labor mobility }\end{array}$ \\
\hline CTAP-1 & 32.31 & & & \\
\hline CTEM-1 & 31.90 & $-1.3 \%$ & $-22.6 \%$ & \\
\hline CTAP-20 & 25.00 & \multicolumn{2}{|c|}{$-33.7 \%$} & $-41.2 \%$ \\
\hline CTEM-20 & 21.41 & \multicolumn{3}{|c|}{} \\
\hline CTEM-20Lab & 18.99 & & \\
\hline
\end{tabular}

Figures 9 and 10 allow us to further investigate the regional mitigation costs and $\mathrm{CO} 2$ reductions across the three sub-national specifications, CTAP-20, CTEM-20 and CTEM-20Lab. Red and green numbers represent the highest reductions and gains in the most significant regions, respectively. The results for all regions are reported in Tables A.2 and A.3 of the Appendix.

Despite the fact that the Southern regions Apulia, Sardinia and Sicily have recently developed wind and solar, they still remain amongst the most fossil-fuel intensive economies and experience the highest relative GDP losses. A relatively larger reduction in GDP can be observed also in Liguria in the North and Lazio in the Center for the same reason. Conversely, Aosta Valley, Piedmont, Trentino Alto Adige and Emilia-Romagna in the North, and Calabria, Abruzzo and Molise in the South see GDP gains in this experiment ${ }^{8}$. Trentino Alto Adige, Emilia Romagna and Abruzzo have the lowest emission intensities in Italy relative to GDP (Table A.4 of the Appendix). The emission reductions follow the same ranking of the GDP changes, but they tend to be more evenly distributed across the regions (Figure 10). This is largely driven by the growth of renewable technologies

\footnotetext{
${ }^{8}$ Molise attracts investment as it is less abundant in capital relative to the other regions and this pushes up the yield of capital. This huge inflow can bias the results of the policy for this very small region because investment is assumed to be perfectly mobile within Italy.
} 
and/or the regional reshuffling of fossil-fuel power generations as captured in CTAP-20, CTEM-20 and CTEM-20Lab, which is to be investigated in the next sub-sections.

Figure 9: GDP changes (\%) due to carbon price (tax) to achieve a 20\% national CO2 emission reduction in Italy. Red and green numbers represent the highest reductions and gains, respectively, in the most significant regions.

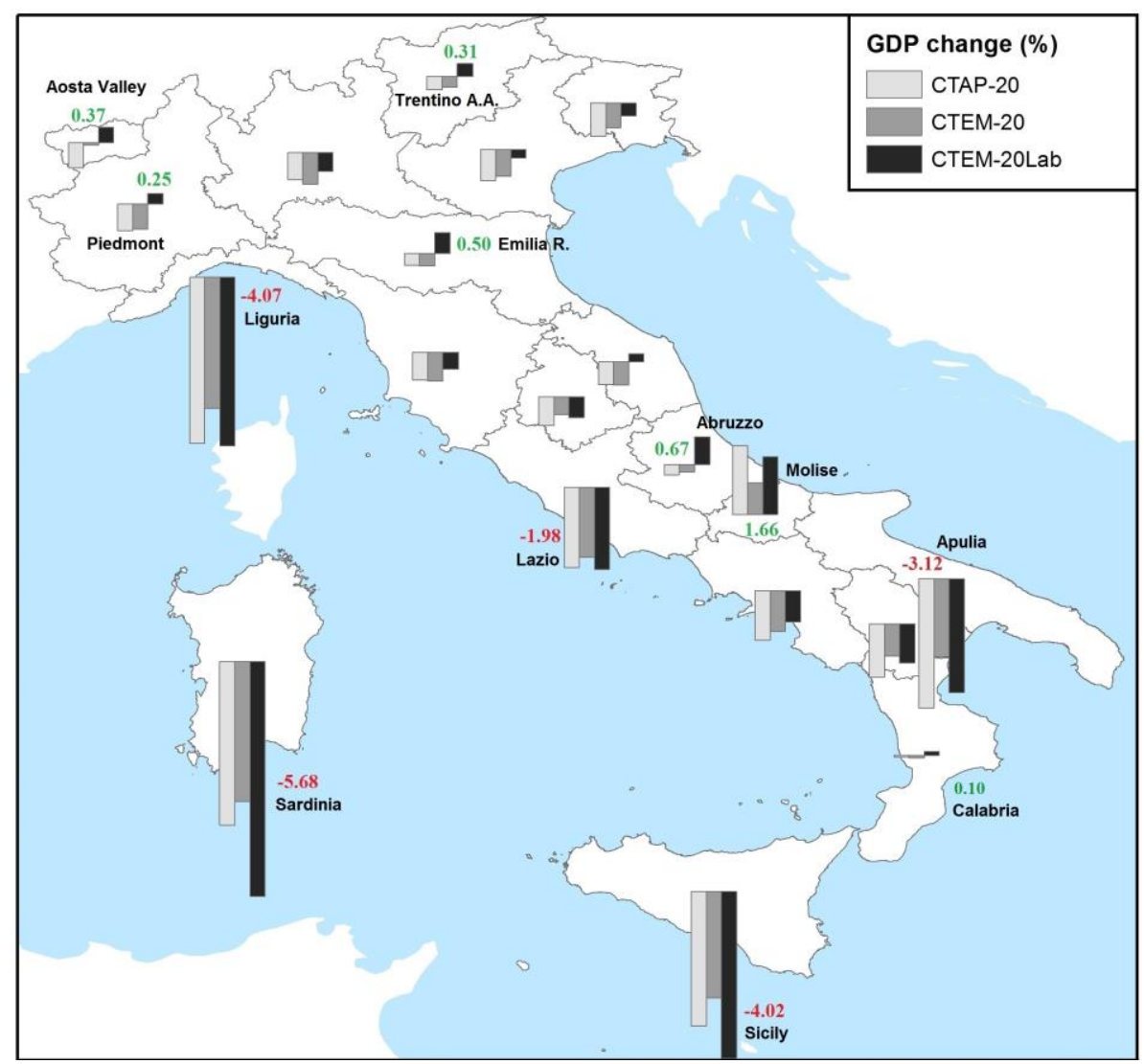


Figure 10: $\mathrm{CO} 2$ Emissions reduction (\%) due to carbon price (tax) to achieve a $20 \%$ national $\mathrm{CO} 2$ emission reduction in Italy. Red numbers represent the highest reductions in the most significant regions.

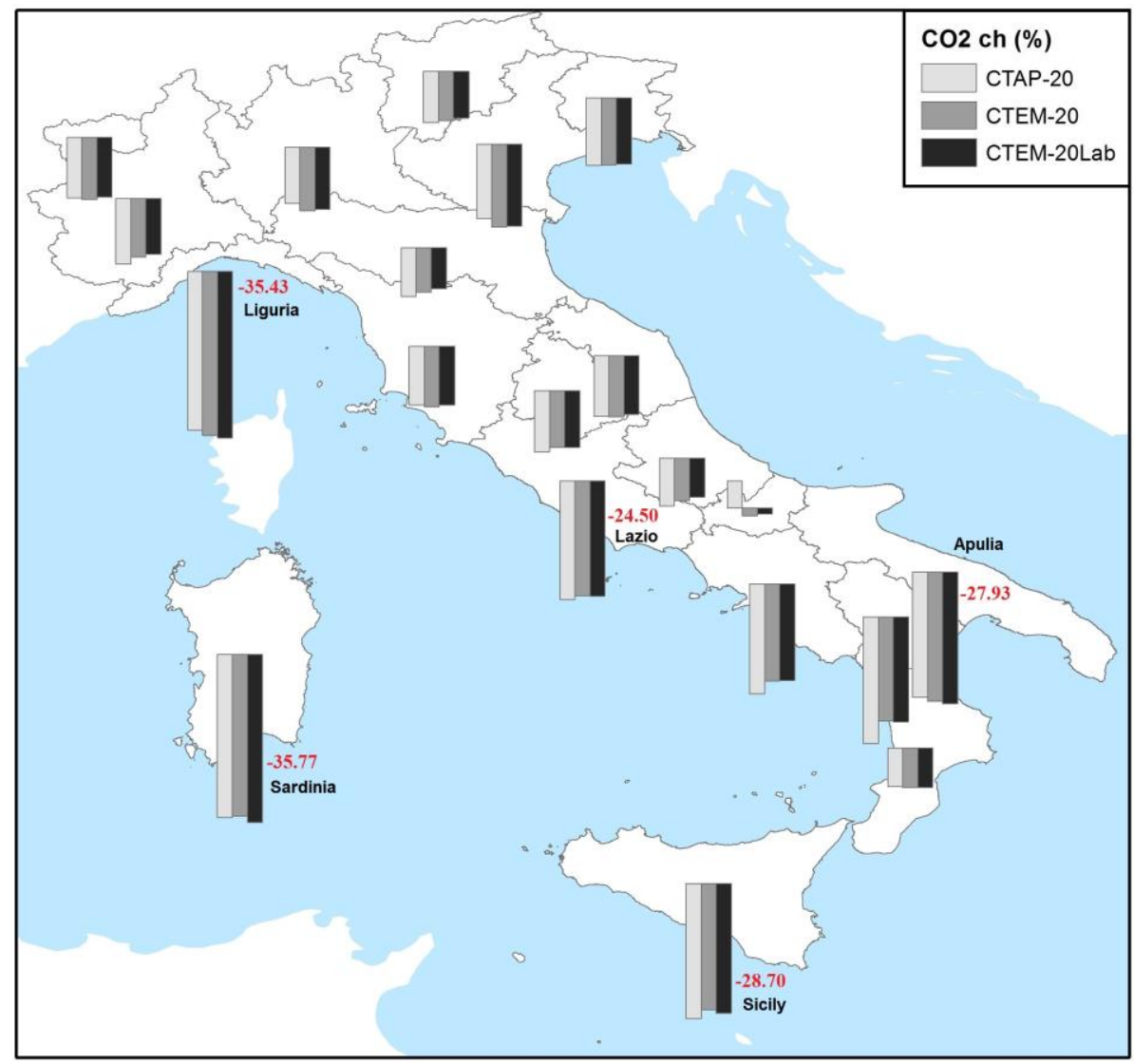

\subsection{Power generation}

In general, either technological or regional disaggregation of the model will lower the predictions on the reduction of power generation (Table 4) due to a $20 \%$ national $\mathrm{CO} 2$ emission reduction in Italy. Specifically, adding electric technology details allows for the shift of electricity production from fossil fuels to renewable technologies ${ }^{9}$; while adding the regional details allows for the shift of fossil-fuel electricity production from less energy efficient regions to the more energy efficient regions. Our simulation results suggest that the second factor $(35.4 \%$ less reduction in power generation) appears to be seven times more important than the first (5.0\% less reduction in power generation). However, the interaction between the two factors is strong, leading to $44.2 \%$ less reduction in power generation. Both two factors allow Italy to decarbonize the power sector (Table 5) and achieve the national mitigation target while cutting less electricity consumption.

\footnotetext{
${ }^{9}$ In CTAP-1, the technological shift is proxied by the shift toward higher share costs of labor and capital and less oil, coal and gas. This simplified approach does not reflect the different cost structures and fossil fuel dependence of various generation technologies, and does not allow the model to explore their potential in absorbing the impacts of carbon pricing. It therefore tends to predict high reduction of power generation (Cai and Arora, 2015).
} 
Table 4: Reduction of power generation due to a $20 \%$ national $\mathrm{CO} 2$ emission reduction in Italy and the estimated effects of disaggregating regions and electric technologies

\begin{tabular}{|c|c|c|c|c|}
\hline & $\begin{array}{c}\text { Power generation } \\
(\% \text { reduction from 2007) }\end{array}$ & $\begin{array}{c}\text { Effect of regional } \\
\text { disaggregation }\end{array}$ & $\begin{array}{c}\text { Effect of tech } \\
\text { disaggregation }\end{array}$ & $\begin{array}{c}\text { Effect of adding } \\
\text { labor mobility }\end{array}$ \\
\hline CTAP-1 & 18.1 & & & \\
\hline CTEM-1 & 17.2 & $-35.4 \%$ & & \\
\hline CTAP-20 & 11.7 & \multicolumn{2}{|c|}{$-44.2 \%$} & \\
\hline CTEM-20 & 10.1 & \multicolumn{2}{|c|}{$-43.6 \%$} & \\
\hline CTEM-20Lab & 10.2 &
\end{tabular}

Table 5: Change of electric sector $\mathrm{CO} 2$ emissions due to a $20 \%$ national $\mathrm{CO} 2$ emission reduction in Italy (\% change from the 2007 level)

\begin{tabular}{|l|r|r|r|r|r|}
\hline & CTAP-1 & CTEM-1 & CTAP-20 & CTEM-20 & CTEM-20Lab \\
\hline Piedmont & n.a & n.a & 5.7 & -0.1 & 0.6 \\
\hline Aosta Valley & n.a & n.a & 14.6 & 4.6 & 5.0 \\
\hline Lombardy & n.a & n.a & -9.5 & -21.7 & -21.4 \\
\hline Trentino AA & n.a & n.a & 12.6 & 2.6 & 3.1 \\
\hline Veneto & n.a & n.a & -23.2 & -36.6 & -36.2 \\
\hline Friuli VG & n.a & n.a & -11.5 & -18.6 & -18.3 \\
\hline Liguria & n.a & n.a & -38.0 & -46.3 & -46.7 \\
\hline Emilia-Romagna & n.a & n.a & 6.4 & 2.5 & 3.2 \\
\hline Tuscany & n.a & n.a & -4.8 & -17.5 & -17.1 \\
\hline Umbria & n.a & n.a & -11.6 & -14.6 & -14.6 \\
\hline Marche & n.a & n.a & -22.8 & -29.9 & -29.2 \\
\hline Lazio & n.a & n.a & -31.5 & -41.7 & -41.8 \\
\hline Abruzzo & n.a & n.a & 14.3 & 11.1 & 11.7 \\
\hline Molise & n.a & n.a & 89.2 & 43.5 & 43.4 \\
\hline Campania & n.a & n.a & 9.4 & 6.8 & 7.1 \\
\hline Apulia & n.a & n.a & -26.7 & -34.1 & -34.5 \\
\hline Basilicata & n.a & n.a & -60.9 & -49.4 & -49.0 \\
\hline Calabria & n.a & n.a & 76.0 & 52.7 & 52.3 \\
\hline Sicily & n.a & n.a & -40.6 & -42.1 & -42.7 \\
\hline Sardinia & n.a & n.a & -48.4 & -51.1 & -51.9 \\
\hline Italy & $\mathbf{- 2 1 . 2}$ & $\mathbf{- 2 7 . 9}$ & $\mathbf{- 2 5 . 7}$ & $\mathbf{- 3 3 . 8}$ & $\mathbf{- 3 3 . 9}$ \\
\hline
\end{tabular}


The effects of regional specialization are evident in Tables 6 and $7^{10}$. The fossil-fuel-intensive regions, such as Liguria, Lazio, Apulia, Sicily and Sardinia, decrease their electric production (Table 6) but are able to add large shares of renewables into their power generation (Table 7). In contrast, regions like Emilia Romagna, Abruzzo, Molise, Campania and Calabria see growth in both fossil-fuel and renewable power technologies (Table 7) and this results in an increase of the electric production (Table 6). These outcomes describe the economic efficiency gains linked to the two factors already mentioned in the previous sub-section. It is also interesting to note that the efficiency gain in fossil-fuel power technologies of the regions mitigates the overall growth of renewables except hydropower in Italy (Table 7, last two rows).

Table 6: Change of electricity production due to a $20 \%$ national $\mathrm{CO} 2$ emission reduction in Italy

(\% change from the 2007 level)

\begin{tabular}{|l|r|r|r|r|r|}
\hline & CTAP-1 & CTEM-1 & CTAP-20 & CTEM-20 & CTEM-20Lab \\
\hline Piedmont & n.a. & n.a. & 8.3 & 3.3 & 3.9 \\
\hline Aosta Valley & n.a. & n.a. & 17.7 & 25.2 & 25.5 \\
\hline Lombardy & n.a. & n.a. & -7.2 & -7.2 & -7.0 \\
\hline Trentino AA & n.a. & n.a. & 15.8 & 13.9 & 14.2 \\
\hline Veneto & n.a. & n.a. & -20.0 & -16.9 & -16.5 \\
\hline Friuli VG & n.a. & n.a. & -8.0 & -6.1 & -5.9 \\
\hline Liguria & n.a. & n.a. & -35.7 & -30.8 & -31.4 \\
\hline Emilia-Romagna & n.a. & n.a. & 9.1 & 5.2 & 5.9 \\
\hline Tuscany & n.a. & n.a. & -2.2 & -4.3 & -4.0 \\
\hline Umbria & n.a. & n.a. & -7.7 & 1.1 & 1.0 \\
\hline Marche & n.a. & n.a. & -21.0 & -21.9 & -21.3 \\
\hline Lazio & n.a. & n.a. & -28.7 & -26.9 & -27.1 \\
\hline Abruzzo & n.a. & n.a. & 17.0 & 17.9 & 18.5 \\
\hline Molise & n.a. & n.a. & 94.8 & 55.1 & 54.8 \\
\hline Campania & n.a. & n.a. & 12.0 & 14.9 & 15.1 \\
\hline Apulia & n.a. & n.a. & -23.8 & -12.7 & -13.4 \\
\hline Basilicata & n.a. & n.a. & -59.8 & -30.5 & -30.2 \\
\hline Calabria & n.a. & n.a. & 81.1 & 63.7 & 63.3 \\
\hline Sicily & n.a. & n.a. & -39.1 & -32.9 & -33.6 \\
\hline Sardinia & n.a. & n.a. & -47.2 & -44.3 & -45.3 \\
\hline Italy & $\mathbf{- 1 8 . 1}$ & $\mathbf{- 1 7 . 2}$ & $\mathbf{- 1 1 . 7}$ & $\mathbf{- 1 0 . 1}$ & $\mathbf{- 1 0 . 2}$ \\
\hline
\end{tabular}

\footnotetext{
${ }^{10}$ Some great variations can be observed in Table 7 . They depend on very small values in the database for the reference year 2007. For instance the very strong growth of waste and wind in Liguria start from a very low initial values.
} 
Table 7: Change of power technology in the electricity sector in CTEM-20

(\% change from the 2007 level)

\begin{tabular}{|c|c|c|c|c|c|c|c|c|c|}
\hline & Coal & Oil & Gas & Hydro & Wind & Solar & Biomass & Waste & Geoth. \\
\hline Piedmont & 9.9 & 1.8 & -2.1 & 10.3 & 0.0 & 19.9 & 23.9 & 23.6 & 0.0 \\
\hline Aosta Valley & 26.4 & 12.7 & -31.3 & 25.3 & 0.0 & 0.0 & 0.0 & 0.0 & 0.0 \\
\hline Lombardy & 9.9 & -2.3 & -24.8 & 18.0 & 0.0 & 61.4 & 72.1 & 72.3 & 0.0 \\
\hline Trentino AA & 16.5 & 5.5 & -11.0 & 15.6 & 24.7 & 22.9 & 28.8 & 28.7 & 0.0 \\
\hline Veneto & -45.8 & -17.6 & -17.9 & 6.8 & 0.0 & 59.8 & 63.3 & 63.0 & 0.0 \\
\hline Friuli VG & -24.9 & -11.7 & -2.2 & 2.9 & 0.0 & 22.9 & 23.9 & 23.7 & 0.0 \\
\hline Liguria & -56.1 & -30.2 & -27.6 & 7.6 & 129.8 & 0.0 & 0.0 & 140.9 & 0.0 \\
\hline Emilia-Romagna & 9.8 & 2.0 & 3.9 & 9.2 & 15.2 & 14.6 & 18.6 & 18.4 & 0.0 \\
\hline Tuscany & 5.9 & -4.0 & -23.6 & 5.7 & 21.7 & 20.4 & 29.1 & 29.1 & 20.9 \\
\hline Umbria & -21.4 & -6.1 & 5.4 & 8.3 & 28.1 & 27.2 & 31.2 & 31.2 & 0.0 \\
\hline Marche & -4.0 & -17.6 & -31.7 & 5.2 & 0.0 & 54.6 & 0.0 & 56.6 & 0.0 \\
\hline Lazio & -50.5 & -23.4 & -27.4 & 3.4 & 65.1 & 64.7 & 66.6 & 67.2 & 0.0 \\
\hline Abruzzo & 19.4 & 10.4 & 19.3 & 16.8 & 22.4 & 20.8 & 27.9 & 27.8 & 0.0 \\
\hline Molise & 55.9 & 44.5 & 57.4 & 44.1 & 44.8 & 0.0 & 63.0 & 63.5 & 0.0 \\
\hline Campania & 15.6 & 6.3 & 16.5 & 13.6 & 18.9 & 17.5 & 0.0 & 23.5 & 0.0 \\
\hline Apulia & -43.5 & -19.8 & -7.3 & 0.0 & 39.2 & 35.5 & 51.8 & 52.1 & 0.0 \\
\hline Basilicata & -24.7 & -36.6 & -51.0 & -16.9 & 19.5 & 0.0 & 19.1 & 19.2 & 0.0 \\
\hline Calabria & 64.9 & 52.5 & 66.2 & 51.0 & 53.2 & 47.4 & 74.3 & 74.4 & 0.0 \\
\hline Sicily & -17.1 & -32.5 & -43.1 & -7.8 & 62.9 & 59.7 & 72.0 & 73.3 & 0.0 \\
\hline Sardinia & -56.2 & -44.1 & -50.3 & -18.3 & 49.9 & 48.5 & 52.5 & 54.2 & 0.0 \\
\hline Italy CTEM-20 & $\mathbf{- 1 5 . 6}$ & $\mathbf{- 1 2 . 5}$ & $\mathbf{- 1 6 . 6}$ & $\mathbf{1 3 . 4}$ & $\mathbf{4 1 . 6}$ & $\mathbf{3 6 . 8}$ & $\mathbf{5 0 . 4}$ & $\mathbf{5 8 . 4}$ & $\mathbf{2 0 . 9}$ \\
\hline Italy CTEM-1 & $\mathbf{- 3 3 . 5}$ & $\mathbf{- 1 4 . 0}$ & $\mathbf{- 2 8 . 6}$ & $\mathbf{1 2 . 7}$ & $\mathbf{7 4 . 8}$ & $\mathbf{7 1 . 6}$ & $\mathbf{8 6 . 5}$ & $\mathbf{8 6 . 5}$ & $\mathbf{7 1 . 4}$ \\
\hline
\end{tabular}

\subsection{Labor movement}

Increasing the flexibility in the labor market decreases the overall cost of the policy for Italy (Table 3 and Table A.1). This is not surprising given the theoretical structure of the model based on competitive markets. In CTEM-20Lab workers migrate mainly from South (Sicily, Sardinia, Apulia and Basilicata) to North (Piedmont, Lombardy, Veneto and Emilia-Romagna). This results in changing the magnitude and sign of the cost impacts in many regions (Table A.1 in the Appendix). In particular, Lazio in the Central region and Apulia, Sicily and Sardinia in the Southern see greater costs impacts, whereas Piedmont and Emilia Romagna in the North show GDP gains rather losses, and Lombardy, Veneto, and Liguria in the North and Tuscany in the Central show smaller GDP losses after accounting for labor mobility. 
This outcome is consistent with the fact that Southern regions are relatively more labor abundant while Northern regions are more capital abundant. When labor mobility is introduced within Italy Southern workers can move toward North where the labor supply is smaller relative to the demand and wages are higher. The increase in labor supply translates in a GDP increase or smaller GDP losses of the above-mentioned Northern regions. Conversely, the Southern regions (Sicily, Sardinia, Apulia and Basilicata) decrease their labor force and experience greater GDP reductions.

\subsection{Economic interpretation of the results}

The key intuition behind our modeling results is the benefit of the sub-national sectoral/technological specialization and intra-national trade. In fact, the results are a natural consequence of the well known Heckscher-Ohlin theorem (Feenstra, 2013) applied to sub-national entities. The theorem states that countries can gain from trade by specializing in producing the good, which uses more intensively the relative abundant/cheap input. In the context of modeling a climate policy, the disaggregation of regional and electric technological details allows the market to explore the regional comparative advantages in either renewable energy source or energy efficiency, and to arrive at a cost-minimizing mitigation profile. In contrast, overlooking the subnational technological and socio-economic differences in energy production and consumption tends to lead to overestimation of the carbon price and the consequential economic losses.

In Figure 11, we demonstrate graphically the application of the Heckscher-Ohlin theorem to an emission target policy. Let us consider a country that is made up of two regions and two goods (coal power and hydropower). The two green curves represent the frontiers of productive possibilities (FPP) of the two regions, respectively. Region 1 is rich in coal reserve while Region 2 has more hydro resources. When these regional differences are overlooked in an aggregated CGE model, the national average FPP is represented by the red curve. The economic equilibrium takes place in E, where the FPP is tangent to utility level curve (U1). When sub-national details are introduced into the modeling, the equilibrium moves from E to E'. The two regions take advantage of their different endowment composition in electricity generation. They specialize in an efficient way according to their FPPs and supply electricity to the national grid as guided by the price curve P in purple color. Overall, the country will be economically better off due to increased consumption of electricity ${ }^{11}$.

\footnotetext{
${ }^{11}$ Figure 11 is a graphical simplification. The new equilibrium E' sees an increase of consumption in both hydro and coal electricity. The increase of coal electricity can be interpreted as the result of improved energy efficiency in the use of coal. In addition in the CGE model the welfare gains also stem from sectoral specialization in the non- electric sectors of the whole economy.
} 
Figure 11: Welfare improvement as a result of inter-regional trade

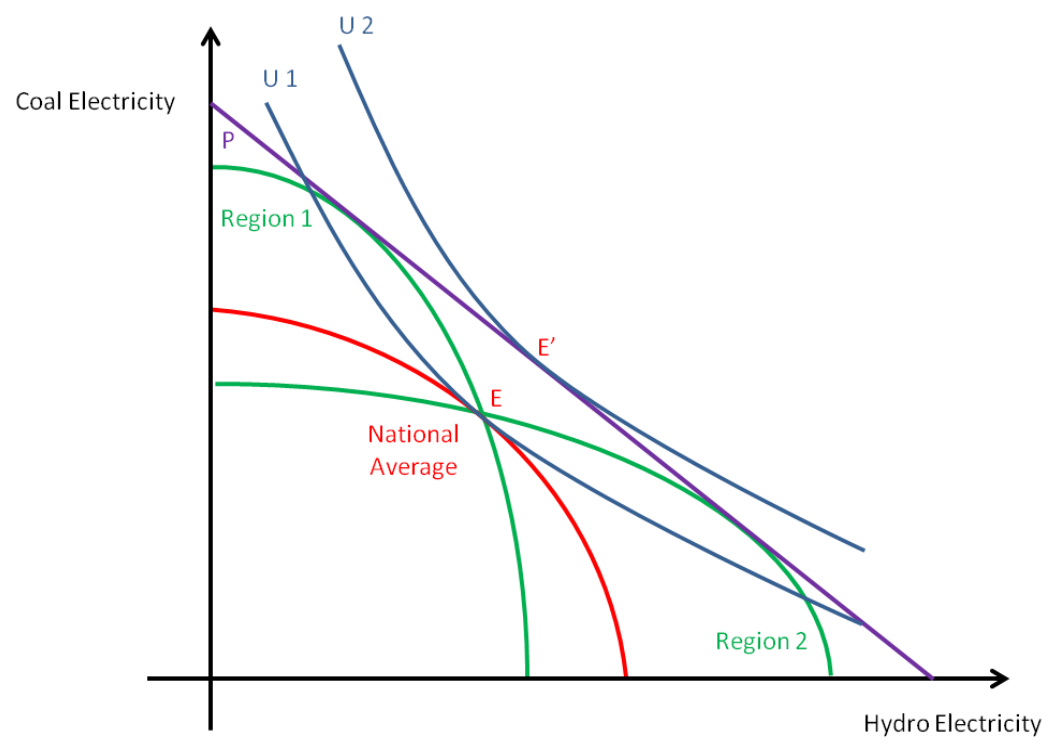

Our arguments are consistent with the trade literature pointing out the underestimation of welfare gains following trade liberalization using aggregated general equilibrium models and average aggregated tariff (Narayanan et al., 2010; Anderson and van Wincoop, 2004; Hillberry, 2002; Pomfret, 1985; Trefler, 1993, Gaston and Trefler, 1994, 1997; Beghin and Kherallah, 1994; Goldberg, 1995; Olarreaga and Soloaga, 1998; Beghin and Fang, 2002).

While our simulation results are limited to the Italian case study, our economic explanation can be generalized to different countries and policy scenarios. This is because intra-national trade exists in every country and sub-national entities are different in terms of sectoral or technological specialization.

\section{Concluding remarks}

Very few studies exist today to explore the importance of model uncertainty, particularly in the area of climate abatement policies. CGE models as other macro-economic models with similar characteristics represent a popular tool to estimate mitigations costs of climate abatement policies, identify the distributional impacts and guide policy decisions. In this work we systematically analyze the role that technological and regional aggregations have in CGE models applied to a climate policy simulation. A deeper and clearer understanding on the underlying economic dynamics affected by the two fundamental model structure assumptions is critical to the understanding of the robustness of the results generated by these types of models. 
Our results show that the prediction for abatement costs of a carbon policy in Italy can change substantially according to different geographical and technological scales of a CGE model. This work also underlines the importance to consider comparative advantages within the country (intranational trade and technological/sectoral specialization at the sub-national level) to explain the mitigation costs of a carbon policy. In particular in our case study, different endowment composition in electricity generation across regions can lead to lesser economic loss due to climate policies and have some implications also for labor movements. The economic explanation behind is more important than the absolute values of results. This is because the results shown here are dependent on the datasets and the assumptions. These data can have uncertainties, and errors or omissions. Especially in the case of a large database at the sub-national level, a part of the relevant information cannot be retrieved directly from the regional accounts but must be derived indirectly by using different techniques. However, the identification of the economic causal links and key variables remains valid and robust.

The insights we provide can be useful not only for the Italy case study but also for the other countries involved in the de-carbonization pathways. Special attention should be paid on the largest countries such as USA, China, Russia, India, Brazil where much greater degree of heterogeneity can be observed within the borders both from an energy-technological and socio-economic point of view.

As a caveat, it should be noted that our results do not suggest which model is "superior". When disaggregating the Italian regions, we have used the same parameterization across the models. This means that sub-national regions behave exactly like countries. Suppose it is a correct modeling practice, then our results do suggest that the aggregated model overestimates the carbon price and economic cost, and that the more disaggregated models perform better. However, it is equivalently possible that our results are suggesting the improperness of using the same parameterization for models with different technological and spatial scales. Economic literature and good sense suggest that this parametrization should be more flexible across the sub-national regions (McCallum, 1995; Anderson and van Wincoop, 2003). A first attempt in this direction has been performed in CTEM$20 \mathrm{Lab}$ for the labor market but a more extensive analysis should be developed for the other markets and parameters. This could represent a good line for further research. 


\section{Acknowledgements}

We thank Mattia Amadio for drawing maps. The authors are responsible for any error and omission in this work. 


\section{References}

ACIL Tasman, 2008. The Impact of an ETS on the Energy Supply Industry, ACIL Tasman, Melbourne.

Anderson, J.E. \& van Wincoop, E., 2003. Gravity with Gravitas: A Solution to the Border Puzzle. American Economic Review, 93 (1), 170-192.

Anderson, J.E. \& van Wincoop, E., 2004. Trade costs. Journal of Economic Literature, 42 (3), 691-751.

Bacharach, M., 1970. Biproportional Matrices \& Input-Output Change. Number 16 in University of Cambridge Department of Applied Economics Monographs. Cambridge University Press.

Barrett, S., Carraro, C. \& de Melo, J., Eds. 2015. Towards a Workable and Effective Climate Regime, CEPR Press and Ferdi.

Beghin, J.C. \& Kherallah, M., 1994. Political institutions and international patterns of agricultural protection. The Review of Economics and Statisitics, 76 (3), 482-489.

Beghin, J.C. \& Fang, C., 2002. Protection and trade liberalization under incomplete market integration. American Journal of Agricultural Economics, 84 (3), 768-773.

Bohringer, C., Rutherford, T. \& Tol, R., 2009, The EU 20/20/20 targets: an Overview of the EMF22. Energy Economics 31, 268-273.

Bosello, F., Campagnolo, L., Carraro, C., Eboli, F., Parrado, R. \& Portale, E., 2013. Macroeconomic Impacts of the EU 30\% GHG Mitigation Target, Working Papers 2013.28, Fondazione Eni Enrico Mattei.

Brink, C., Vollebergh H., Verdonk, M. \& van der Werf, E., 2014. Quantifying the Effects of Reforming the EU Emissions Trading System. A Computable General Equilibrium Analysis. Fifth World Congress of Environmental and Resource Economists, Istanbul, Turkey.

Cai, Y. \& Arora, V., 2015. Disaggregating electricity generation technologies in CGE models: A revised technology bundle approach with an application to the U.S. Clean Power Plan, Applied Energy, vol. 154(C), pp. 543-555.

Cai, Y., Newth, D., Finnigan, J. \& Gunasekera, D., 2015. A hybrid energy-economy model for global integrated assessment of climate change, carbon mitigation and energy transformation, Applied Energy, vol. 148(C), pp. 381-395.

Canning, P. \& Tsigas, M., 2000. Regionalism, Federalism, and Taxation: A Food and Farm Perspective. Technical Bulletin No. 1882, Economic Research Services, U.S. Department of agriculture.

Carraro, C., Edenhofer, O. \& Hourcade, J.C., 2012. On the Economics of Decarbonization in an Imperfect World. Climatic Change, Vol 114, Issue 1, pp. 1-8.

Carrera, L., Standardi, G., Bosello, F. \& Mysiak, J., 2015. Assessing direct and indirect economic impacts of a flood event through the integration of spatial and computable general equilibrium modelling. Environmental Modelling and Software. Vol. 63, pp. 109-122.

Catoni, P.G. \& Iorio, G., 2011. ENEA. L’energia delle regioni. Available at: http://www.enea.it/it/pubblicazioni/pdf-volumi/V2011EnergiaRegioni.pdf

Chintrakarn, P. \& Millimet, D.L., 2006. The Environmental Consequences of Trade: Evidence from Subnational Trade Flows. Journal of Environmental Economics and Management, 52(1), 430-453.

Commonwealth of Australia, 2008. Australia's Low Pollution Future: The Economics of Climate Change Mitigation, Commonwealth of Australia, Canberra.

Commonwealth of Australia, 2011. Strong Growth, Low Pollution: Modelling a Carbon Price, Commonwealth of Australia, Canberra.

Deming, W.E. \& Stephan, F.F.,1940.. On a Least-squares Adjustment of a Sampled Frequency Table when the Expected Marginal Totals are Known. Annals of Mathematical Statistics, 11, 427-444. 
Dixon, P., Rimmer, M. \& Wittwer, G., 2012. USAGE-R51, a state-level multi-regional CGE model of the US economy. Presented at the 15th Annual Conference on Global Economic Analysis, Geneva (Switzerland).

Dubé, J. \& Lemelin, A., 2005. Estimation Expérimentale des Flux d'Echanges Interrégionaux par la Méthode de Minimisation de l'Entropie Croisée. Revue Canadienne des Sciences Régionales/Canadian Journal of Regional Science, 28(3), 513-534.

Durand-Lasserve, O., Pierreu, A. \& Smeers Y., 2010, Uncertain Long-Run Emissions Targets, CO2 Price and Global Energy Transition: a General Equilibrium Approach. CORE Discussion Paper No 2010.27, June 2010.

EIA, US Energy Information Administration, 2012. Fuel competition in power generation and elasticities of substitution.

EIA, US Energy Information Administration, 2013. Updated capital cost estimates for utility scale electricity generating plants.

EIA, US Energy Information Administration, 2014. The Electricity Market Module.

European Council, 2014. Conclusions - 23/24 October 2014: I. 2030 Climate and Energy Policy Framework, EUCO 160/14. Brussels.

Fawcett, A. A., Clarke, L. E. \& Weyant J. P., 2014. The EMF24 Study on U.S. Technology and Climate Policy Strategies. The Energy Journal Special Issue 35(1).

FCCC, 2015. Adoption of the Paris Agreement. Proposal by the President. Draft decision -/CP.21. http://unfccc.int/resource/docs/2015/cop21/eng/109.pdf.

Feenstra, R., 2003. Advanced International Trade: Theory and Evidence. Princeton University Press.

Gaston, N. \& Trefler, D., 1994. Trade and wages: evidence from U.S. manufacturing. Industrial and Labor Relations Review, 47 (4), 574-593.

Gaston, N. \& Trefler, D., 1997. The labour market consequences of the Canada-U.S. free trade agreement. The Canadian Journal of Economics, 30 (1), 18-41.

Goldberg, P.K., 1995. Product differentiation and oligopoly in international markets: the case of the U.S. automobile industry. Econometrica, 63 (4), 891-951.

Gough, I., 2013. Carbon Mitigation Policies, Distributional Dilemmas and Social Policies. Journal of Social Policy, 42(02): 191-213.

Hanoch, G., 1971. CRESH production functions. Econometrica, 39: 695-712.

Hertel, T., 1997. Global trade analysis modelling and applications, Cambridge: Cambridge University Pres.

Hillberry, R.H., 2002. Aggregation bias, compositional change and the border effect. The Canadian Journal of Economics, 35 (3), 517-530.

Hu, J., Crijns-Graus, W., Lam L. \& Gilbert, A., 2015. Ex-ante evaluation of EU ETS during 2013-2030: EU-internal abatement. Energy Policy, 77: 152-163.

IEA, 2013. World Energy Outlook 2013. International Energy Agency. ISTAT. Agricoltura e Zootecnia. http://agri.istat.it/sag_is_pdwout/index.jsp

IPCC, 2014a: Summary for Policymakers. In: Climate Change 2014: Impacts, Adaptation, and Vulnerability. Part A: Global and Sectoral Aspects. Contribution of Working Group II to the Fifth Assessment Report of the Intergovernmental Panel on Climate Change (Field, C.B., V.R. Barros, D.J. Dokken, K.J. Mach, M.D. Mastrandrea, T.E. Bilir, M. Chatterjee, K.L. Ebi, Y.O. Estrada, R.C. Genova, B. Girma, E.S. Kissel, A.N. Levy, S. MacCracken, P.R. Mastrandrea, and L.L. White (eds.)). Cambridge University Press, Cambridge, United Kingdom and New York, NY, USA, pp. 1-32. 
IPCC, Ed. 2014b. Climate Change 2014: Mitigation of Climate Change. Contribution of Working Group III to the Fifth Assessment Report of the Intergovernmental Panel on Climate Change. Cambridge, United Kingdom and New York, NY, USA, Cambridge University Press.

ISTAT. Agricoltura e Zootecnia. http://agri.istat.it/sag_is_pdwout/index.jsp

ISTAT. Conti Economici Regionali. Anni 1995-2009. http://www.istat.it/it/archivio/12718

ISTAT. Trasporto Aereo. 2003-2009. http://www.istat.it/it/archivio/14035

ISTAT. Trasporto Ferroviario. 2004-2009. http://www.istat.it/it/archivio/12909

ISTAT. Trasporto Marittimo. 2005-2008. http://www.istat.it/it/archivio/14084

ISTAT. Trasporto Merci su Strada. 2008-2009. http://www.istat.it/it/archivio/34954

ISTAT. Valore Aggiunto ai Prezzi di Base dell'Agricoltura per Regione. Anni $1980-2011$. http://www.istat.it/it/archivio/66513

ISTAT-ICE, 2008. Commercio estero e attività internazionali delle imprese. Annuario 2007.

Latvian Presidency of the Council of the European Union, 2015. Intended Nationally Determined Contribution of the EU and its Member States.

Luderer, G., Bosetti, V., Jakob, M., Leimbach, M., Steckel, J., Waisman, H. \& Edenhofer O., 2012. The economics of decarbonizing the energy system-results and insights from the RECIPE model intercomparison. Climatic Change, 114(1): 9-37.

Mancuso, E., 2010. ENEA. Inventario annuale delle emissioni di gas serra su scala regionale. Available at: http://old.enea.it/produzione_scientifica/pdf_volumi/V2010_04-InventarioEmissioniGas.pdf

McCallum, J., 1995. National Borders Matter: Canada-U.S. Regional Trade Patterns. American Economic Review, 85(3), 615-23.

McKibbin, W., Morris, A. \& Wilcoxen, P., 2010. Comparing climate commitments: A model-based analysis of the Copenhagen Accord. Harvard Project on International Climate Agreements Discussion Paper no. 10-35, Harvard Kennedy School.

Miller, R.E. \& Blair, P.D., 2009. Input-Output Analysis: Foundations and Extensions. Cambridge University Press, Cambridge.

Narayanan B., Aguiar, A. \& McDougall R., 2012. Global Trade, Assistance, and Production: The GTAP 8 Data Base, Center for Global Trade Analysis, Purdue University.

Narayanan, B., Hertel, T. \& Horridge, M., 2010. Disaggregated data and trade policy analysis: The value of linking partial and general equilibrium models, Economic Modelling, Elsevier, vol. 27(3), pages 755-766, May.

Olarreaga, M. \& Soloaga, I., 1998. Endogenous tariff formation: the case of Mercosur. The World Bank Economic Review 12 (2), 297-320.

Orecchia, C. \& Parrado, R., 2013. A Quantitative Assessment of the Implications of Including non-CO2 Emissions in the European ETS, Working Papers 2013.100, Fondazione Eni Enrico Mattei.

Pant H., 2007. GTEM: Global Trade and Environment Model. ABARE Technical Report. Canberra: Australian Bureau of Agricultural and Resource Economics and Sciences.

Pearce D., 2012. Designing a Carbon Price Policy: Empirical Uncertainties in Climate Policy Implementation. Australian Economic Review. 45 (1), 114-124. 
Peterson E.B., Schleich, J. \& Duscha, V., 2011, Environmental and economic effects of the Copenhagen pledges and more ambitious emission reduction targets. Energy Policy, 39, pp. 3697-3708.

Pomfret, R., 1985. Categorical aggregation and international trade: a comment. The Economic Journal. 95 (378), 483485.

Standardi G., Bosello F. \& Eboli F., 2014. A Sub-national CGE Model for Italy, Working Papers 2014.04, Fondazione Eni Enrico Mattei.

TERNA. L'elettricità nelle regioni. Anno 2007. Available at: http://download.terna.it/terna/0000/0113/40.pdf

TERNA. L'elettricità nelle regioni. Anno 2013. Available at: http://download.terna.it/terna/0000/0113/50.pdf

Trefler, D., 1993. Trade liberalization and the theory of endogenous protection: an econometric study of U.S. import policy. The Journal of Political Economy. 101 (1), 138-160.

Wittwer, G. \& Horridge, M., 2010. Bringing Regional Detail to a CGE Model using Census Data. Spatial Economic Analysis, Vol. 5, pp. 229-255. 


\section{Appendix A}

Table A1: Mitigation costs expressed as real GDP losses (2007 billion US\$)

\begin{tabular}{|c|c|c|c|c|c|}
\hline & CTAP-1 & CTEM-1 & CTAP-20 & CTEM-20 & CTEM-20Lab \\
\hline Piedmont & n.a. & n.a. & -1.11 & -1.05 & 0.43 \\
\hline Aosta Valley & n.a. & n.a. & -0.03 & 0.00 & 0.02 \\
\hline Lombardy & n.a. & n.a. & -3.01 & -3.46 & -2.11 \\
\hline Trentino Alto Adige & n.a. & n.a. & -0.13 & -0.10 & 0.12 \\
\hline Veneto & n.a. & n.a. & -1.51 & -1.29 & -0.40 \\
\hline Friuli Venezia Giulia & n.a. & n.a. & -0.38 & -0.28 & -0.14 \\
\hline Liguria & n.a. & n.a. & -2.34 & -1.84 & -2.38 \\
\hline Emilia Romagna & n.a. & n.a. & -0.56 & -0.59 & 0.97 \\
\hline Tuscany & n.a. & n.a. & -0.94 & -0.98 & -0.57 \\
\hline Umbria & n.a. & n.a. & -0.20 & -0.12 & -0.15 \\
\hline Marche & n.a. & n.a. & -0.31 & -0.31 & 0.11 \\
\hline Lazio & n.a. & n.a. & -4.17 & -3.63 & -4.28 \\
\hline Abruzzo & n.a. & n.a. & -0.10 & -0.07 & 0.27 \\
\hline Molise & n.a. & n.a. & 0.16 & 0.07 & 0.13 \\
\hline Campania & n.a. & n.a. & -1.52 & -1.24 & -0.96 \\
\hline Apulia & n.a. & n.a. & -3.03 & -1.81 & -2.66 \\
\hline Basilicata & n.a. & n.a. & -0.21 & -0.13 & -0.16 \\
\hline Calabria & n.a. & n.a. & -0.01 & -0.03 & 0.04 \\
\hline Sicily & n.a. & n.a. & -3.79 & -2.99 & -4.69 \\
\hline Sardinia & n.a. & n.a. & -1.81 & -1.55 & -2.60 \\
\hline Italy & -32.31 & -31.90 & -25.00 & -21.41 & -18.99 \\
\hline Rest of Europe & 3.33 & 2.89 & 2.30 & 1.95 & 1.95 \\
\hline Rest of the World & 1.81 & 1.51 & 0.84 & 0.69 & 0.65 \\
\hline World & -27.17 & -27.51 & -21.86 & -18.77 & -16.38 \\
\hline
\end{tabular}

Source: Simulation results 
Table A.2: Mitigation costs expressed as real GDP losses (\% change from the 2007 level)

\begin{tabular}{|l|r|r|r|}
\hline & CTAP-20 & CTEM-20 & CTEM-20Lab \\
\hline Piedmont & -0.64 & -0.61 & 0.25 \\
\hline Aosta Valley & -0.62 & -0.06 & 0.37 \\
\hline Lombardy & -0.66 & -0.76 & -0.46 \\
\hline Trentino Alto Adige & -0.32 & -0.26 & 0.31 \\
\hline Veneto & -0.75 & -0.64 & -0.20 \\
\hline Friuli Venezia Giulia & -0.79 & -0.58 & -0.30 \\
\hline Liguria & -4.01 & -3.16 & -4.07 \\
\hline Emilia Romagna & -0.29 & -0.30 & 0.50 \\
\hline Tuscany & -0.67 & -0.70 & -0.41 \\
\hline Umbria & -0.69 & -0.43 & -0.51 \\
\hline Marche & -0.55 & -0.56 & 0.19 \\
\hline Lazio & -1.93 & -1.68 & -1.98 \\
\hline Abruzzo & -0.25 & -0.18 & 0.67 \\
\hline Molise & 1.66 & 0.77 & 1.40 \\
\hline Campania & -1.20 & -0.98 & -0.76 \\
\hline Apulia & -3.12 & -1.87 & -2.74 \\
\hline Basilicata & -1.29 & -0.78 & -0.95 \\
\hline Calabria & -0.03 & -0.06 & 0.10 \\
\hline Sicily & -3.25 & -2.57 & -4.02 \\
\hline Sardinia & -3.95 & -3.38 & -5.68 \\
\hline Italy & -1.18 & -1.01 & -0.90 \\
\hline & $S i m b$ & \\
\hline
\end{tabular}

Source: Simulation results 
Table A.3: $\mathrm{CO} 2$ abatements

(\% change from the 2007 level)

\begin{tabular}{|l|r|r|r|}
\hline & CTAP-20 & CTEM-20 & CTEM-20Lab \\
\hline Piedmont & -13.91 & -12.47 & -11.82 \\
\hline Aosta Valley & -12.91 & -13.23 & -12.76 \\
\hline Lombardy & -11.98 & -13.54 & -13.23 \\
\hline Trentino Alto Adige & -10.74 & -10.33 & -9.89 \\
\hline Veneto & -15.85 & -17.64 & -17.35 \\
\hline Friuli Venezia Giulia & -14.27 & -14.16 & -13.91 \\
\hline Liguria & -33.80 & -34.92 & -35.43 \\
\hline Emilia Romagna & -10.42 & -9.46 & -8.74 \\
\hline Tuscany & -12.56 & -12.90 & -12.57 \\
\hline Umbria & -13.08 & -12.06 & -12.05 \\
\hline Marche & -12.97 & -13.06 & -12.47 \\
\hline Lazio & -25.21 & -24.42 & -24.50 \\
\hline Abruzzo & -10.18 & -8.98 & -8.28 \\
\hline Molise & 5.83 & -1.60 & -1.19 \\
\hline Campania & -23.41 & -20.71 & -20.58 \\
\hline Apulia & -26.59 & -27.49 & -27.93 \\
\hline Basilicata & -27.02 & -22.20 & -22.36 \\
\hline Calabria & -8.17 & -8.36 & -8.35 \\
\hline Sicily & -28.70 & -26.86 & -27.54 \\
\hline Sardinia & -34.71 & -34.36 & -35.77 \\
\hline Italy & -20 & -20 & -20 \\
\hline & $S i m b$ & \\
\hline
\end{tabular}

Source: Simulation results 
Table A.4: CO2 Emission Intensity Relative to GDP of the 20 Italian Regions

\begin{tabular}{|l|c|}
\hline & Mt CO2 per 2007 billion US\$ \\
\hline Piedmont & 16.97 \\
\hline Aosta Valley & 17.91 \\
\hline Lombardy & 24.35 \\
\hline Trentino Alto Adige & 15.18 \\
\hline Veneto & 20.68 \\
\hline Friuli Venezia Giulia & 20.72 \\
\hline Liguria & 59.62 \\
\hline Emilia Romagna & 15.54 \\
\hline Tuscany & 19.63 \\
\hline Umbria & 18.40 \\
\hline Marche & 17.36 \\
\hline Lazio & 33.18 \\
\hline Abruzzo & 13.70 \\
\hline Molise & 23.04 \\
\hline Campania & 21.18 \\
\hline Apulia & 43.14 \\
\hline Basilicata & 22.85 \\
\hline Calabria & 18.58 \\
\hline Sicily & 50.13 \\
\hline Sardinia & 62.72 \\
\hline Italy & 26.19 \\
\hline Source Aut & ref \\
\hline
\end{tabular}

Source: Authors' calculation from the database in the reference year (2007) 


\title{
NOTE DI LAVORO DELLA FONDAZIONE ENI ENRICO MATTEI
}

\author{
Fondazione Eni Enrico Mattei Working Paper Series
}

Our Note di Lavoro are available on the Internet at the following addresses:

http://www.feem.it/getpage. aspx? $i d=73 \&$ sez $=$ Publications\&padre=20\&tab $=1$

http://papers.ssrn.com/sol3/JELJOUR_Results.cfm?form_name=journalbrowse\&journal_id=266659 http://ideas.repec.org/s/fem/femwpa.html

http://www.econis.eu/LNG=EN/FAM?PPN=505954494

http://ageconsearch.umn.edu/handle/35978

http://www.bepress.com/feem/

http://labs.jstor.org/sustainability/

\section{NOTE DI LAVORO PUBLISHED IN 2017} Anna Alberini, Milan Ščasný: The Benefits of Avoiding Cancer (or Dying from Cancer): Evidence from a Fourcountry Study

Cesare Dosi, Michele Moretto: Cost Uncertainty and Time Overruns in Public Procurement: a Scoring Auction for a Contract with Delay Penalties

\section{Large and Small Municipalities}

Sara Brzuszkiewicz: The Social Contract in the MENA Region and the Energy Sector Reforms

Berno Buechel, Lydia Mechtenberg: The Swing Voter's Curse in Social Networks

Andrea Bastianin, Marzio Galeotti, Matteo Manera: Statistical and Economic Evaluation of Time Series. Models for Forecasting Arrivals at Call Centers

Robert C. Pietzcker, Falko Ueckerdt, Samuel Carrara, Harmen Sytze de Boer, Jacques Després, Shinichiro Fujimori, Nils Johnson, Alban Kitous, Yvonne Scholz, Patrick Sullivan, Gunnar Luderer: System Integration of Wind and Solar Power in Integrated Assessment Models: a Cross-model Evaluation of New Approaches

Samuel Carrara, Thomas Longden: Freight Futures: The Potential Impact of Road Freight on Climate Policy Claudio Morana, Giacomo Sbrana: Temperature Anomalies, Radiative Forcing and ENSO

Valeria Di Cosmo, Laura Malaguzzi Valeri: Wind, Storage, Interconnection and the Cost of Electricity Generation

Elisa Delpiazzo, Ramiro Parrado, Gabriele Standardi: Extending the Public Sector in the ICES Model with an Explicit Government Institution

Bai-Chen Xie, Jie Gao, Shuang Zhang, ZhongXiang Zhang: What Factors Affect the Competiveness of Power Generation Sector in China? An Analysis Based on Game Cross-efficiency

Stergios Athanasoglou, Valentina Bosetti, Laurent Drouet: A Simple Framework for Climate-Change Policy under Model Uncertainty

Loïc Berger and Johannes Emmerling: Welfare as Simple $(x)$ Equity Equivalents

Christoph M. Rheinberger, Felix Schläpfer, Michael Lobsiger. A Novel Approach to Estimating the Demand Value of Road Safety

Giacomo Marangoni, Gauthier De Maere, Valentina Bosetti: Optimal Clean Energy R\&D Investments Under Uncertainty

Daniele Crotti, Elena Maggi: Urban Distribution Centres and Competition among Logistics Providers: a Hotelling Approach

\section{Quentin Perrier: The French Nuclear Bet}

Gabriele Standardi, Yiyong Cai, Sonia Yeh: Sensitivity of Modeling Results to Technological and Regional Details: The Case of Italy's Carbon Mitigation Policy 